\title{
Elazı̆g Bölgesinin Kırmataş Potansiyeli ve Kullanım Alanları
}

\author{
Crushed Stone Potential of Elazı̆̆ Region and Usage Areas
}

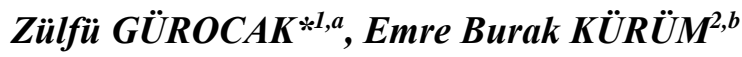 \\ ${ }^{1}$ Firat Üniversitesi, Mühendislik Fakültesi, Jeoloji Mühendisliği Bölümü, Elazığ \\ ${ }^{2}$ Türkiye Büyük Millet Meclisi, Ankara
}

• Geliş tarihi / Received: 05.06.2020 • Düzeltilerek geliş tarihi / Received in revised form: 24.08.2020 • Kabul tarihi / Accepted: 04.09.2020

$\ddot{O} z$

$\mathrm{Bu}$ çalışmada, Elazı̆̆ çevresinde yüzeyleyen kayaçların kırmataş potansiyeli ve kullanım alanları incelenmiştir. Bu amaçla, Keban Metamorfitleri, Kömürhan Ofiyolitleri, Elazı̆̆ Magmatitleri, Harami Formasyonu, Maden Karmaşığı, Seske Formasyonu, Kırkgeçit Formasyonu ve Karabakır Formasyonu'ndan alınan bloklardan agrega örnekleri hazırlanmış ve deneysel çalı̧̧malar yapılmıştır. Laboratuvar çalışmalarından elde edilen sonuçlar, şartname ve standartlarda verilen sınır değerler ile karşılaştırılarak, incelenen kayaçların beton agregası, balast ve yol üst yapı malzemesi olabilirliği ortaya konulmuştur. Bu çalışmadan elde edilen sonuçlar, Elazığ Magmatitleri’ne ait andezitler, Harami Formasyonu'na ait kireçtaşları, Maden Karmaşığı'na ait bazaltlar ve Kırkgeçit Formasyonu'na ait kireçtaşlarının beton agregası olarak kullanılabileceğini göstermektedir. Elazı ̆̆ Magmatitleri'ne ait andezitler demiryolu balastı olarak kullanılmaya uygundur. Ayrıca, Harami, Seske ve Kırkgeçit Formasyonlarına ait kireçtaşları ile Maden Karmaşı̆̆ı'na ait bazaltlar tüm katmanlarda yol üst yapı malzemesi olarak kullanılabilir niteliktedir.

Anahtar kelimeler: Agrega, Balast, Elazığ Bölgesi, Yol Üst Yapı Malzemesi

\begin{abstract}
In this study, the crushed stone potential and usage areas of the formations cropped out around Elazlğ was investigated. For this purpose, aggregate samples were prepared from block samples collected from Keban Metamorphites, Kömürhan Ophiolites, Elazığ Magmatics, Harami Formation, Maden Complex, Seske Formation, Kırkgeçit Formation and Karabakır Formation and experimental studies were conducted. The results obtained from the experiments were compared with the limit values given in the technical specifications and standards and the usability of the rocks as concrete aggregate, ballast and road superstructure material was determined. The results of this study show that the andesites of Elazığ Magmatics, the limestones of Harami Formation, the basalts of Maden Complex and the limestones of Kirkgeçit Formation can be used as concrete aggregate. The andesites of Elazlğ Magmatics are suitable for use as railway ballast. Also, the limestones of Harami, Seske and Kirkgeçit formations and the basalts of Maden Complex are usable in all layers of the road superstructure.
\end{abstract}

Keywords: Agregate, Ballast, Elazı̆̆ Area, Road Superstructure Material

\footnotetext{
*a Zülfü GÜROCAK; zgurocak@ firat.edu.tr, Tel: (0532) 35536 47, orcid.org/ 0000-0002-1049-8346

${ }^{\mathrm{b}}$ orcid.org/0000-0003-0181-157X
} 


\section{Giriş}

Hızla artan temel ihtiyaçlar büyük boyutlu mühendislik yapılarını da (otoyol, köprü, baraj vb.) beraberinde getirmektedir. Doğal olarak, bu yapıların inşası kırmataşa olan ihtiyacı da önemli ölçüde artırmaktadır. Bu nedenle, yeni kırmataş kaynakların bulunması ve mevcut üretim alanlarının geliştirilerek inşaat sektörünün kullanımına sunulması planlanan projelerin gerçekleştirilebilirliği açısından oldukça önemlidir. $\mathrm{Bu}$ amaçla, farklı kökene sahip kayaçların doğal taş endüstrisinde mermer, inşaat sektöründe agrega ve ulaşım sektöründe ise anroşman, balast ve micır olarak kullanılabilirliğinin araştırılması, bölgesel bazda yapılacak çalışmalar ile kırmataş potansiyelinin ortaya konulması gerekmektedir.

Bir kayacın kırmataş olarak kullanılabilirliğini belirleyen temel faktörler, o kayacın kimyasal, fiziksel ve mekanik özellikleridir. Günümüze kadar birçok araştırmacı farklı kökene sahip kayaçların kırmataş olarak değerlendirilebilirliği konusunda gerçekleştirdikleri münferit çalışmalarda (Hartle, 1974; Ramsay vd., 1974; Less ve Kenedy, 1975; Kazi ve Mansour, 1980; Özturan ve Çeçen, 1997; Tasong vd., 1998; Zarif vd., 2003; Korkanç ve Tuğrul, 2004; Gürocak, 2016) bu özellikleri dikkate alarak değerlendirmeler yapmışlardır. Gerek ulusal ve gerekse uluslararası standart kuruluşlarının (TSE, BS, ASTM, CSA gibi) önerdiği standartlar incelendiğinde, her ne kadar sınır değerlerde farklılıklar olsa da bu standartların tamaminda kayacın kimyasal, fiziksel ve mekanik özelliklerinin belli limit değerlere sahip olmas1 gerekliliği vurgulanmaktadır.

Kırmataş konusunda yapılan çalışmalara genel olarak bakıldığında, kayaçların agrega olabilirlikleri konusunda yapılan çalışmaların önemli bir yer tuttuğunu görmek mümkündür. Agrega, doğal (dere yatağı alüvyonu) veya yapay (kırmataş) olarak elde edilen, hazır beton sektöründe beton agregası olarak kullanımı ile birlikte, demiryollarında balast malzemesi, karayolu inşaat sektöründe ise üst yapı malzemesi olarak da kullanılan malzemedir. Betonun imalatında kullanılan ve beton hacminin yaklaşık \% 60-80'ini oluşturan agrega, mineral kökenli ve taneli doğal malzemedir. Beton literatüründe (TSE 706 EN 126020, 2009) kabaca 4.75 mm'den küçük ince taneli malzemeye ince agrega, 4.75 $\mathrm{mm}$ ile en büyük boyut $\left(\mathrm{d}_{\max }=40 \mathrm{~mm}\right)$ arasında olan agregaya ise iri agrega denir.
Literatürde kayaçların kırmataş olarak kullanımı konusunda yapılmış olan bilimsel çalışmalar, istenilen dayanıma sahip kaliteli bir beton üretimi ile sağlıklı ve ekonomik karayolu ve demiryolu inşasının ana ayağını, standartlara uygun özelliklere sahip agrega kullanımının oluşturduğunu ortaya koymaktadır. $\mathrm{Bu}$ nedenle, şehirleşmenin var olduğu alanlar ve yakın çevresinde yüzeyleme veren kayaçların kırmataş olarak kullanılıp kullanılamayacağı konusunda çalışmaların yapılarak, yeni ve kaliteli agrega kaynaklarının kullanıma kazandırılması büyük önem taşımaktadır. Bu konuda ülkemizde yapılan çalışmalara bakıldığında, kayaçların beton agregası (Gürbüz, 1998; Kocal, 1999; Zarif vd., 2003; Zarif ve Tuğrul, 2003; Korkanç ve Tuğrul, 2004; Doğan, 2006; Çokmak, 2007; Öz, 2007; Gürocak, 2016, Güçlüer vd., 2017; Coşkun ve Zorlu, 2018), balast (Oğul vd, 2012; Koralay vd., 2014; Apaydın ve Y1lmaz, 2019) ve yol üst yap1 malzemesi (Kırca, 2001; Tayfur vd., 2003; K1lıç ve Keskin, 2003; Akpınar vd., 2004; Temiz vd., 2006; Karacan, 2006; Davraz vd., 2007, Turabi ve Okucu, 2007; Konak vd., 2009; Akbulut vd., 2009; Yağız, 2010) olarak kullanılabilirliği konusunda bir çok çalışmanın yapıldığını görmek mümkündür. Kayaçların kırmataş olarak kullanılabilirliği konusunda yapılacak olan yeni çalışmalar ile farklı alanlarda yüzeyleme veren kayaçların kırmataş sektörüne kazandırılması önem taşımaktadır.

$\mathrm{Bu}$ çalışmada, Elazı̆̆ İli merkezi ve yakın çevresinde yüzeyleme veren, litolojik olarak kırmataş olabilme potansiyeline sahip olduğu düşünülen, Keban Metamorfitleri'ne ait rekristalize kireçtaşları, Kömürhan Ofiyolitleri'ne ait gabrolar, Elazığ Magmatitleri'ne ait granitler ve andezitler, Harami Formasyonu'na ait kireçtaşları, Seske Formasyonu'na ait kireçtaşları, Maden Karmaşığı'na ait bazaltlar, Kırkgeçit Formasyonu'na ait kireçtaşları ve Karabakır Formasyonu'na ait bazaltların kırmataş olarak kullanılabilirliği incelenmiştir. $\mathrm{Bu}$ amaçla, arazi ve laboratuvar çalışmaları gerçekleştirilmiş, elde edilen veriler standartlarda önerilen limit değerler ile karşılaştırılarak, incelenen kayaçların beton agregası, balast ve yol üstyap1 malzemesi olarak kullanılabilirlikleri belirlenmiştir.

\section{Bölgenin Jeolojik Özellikleri}

Ketin (1966) Türkiye arazisini tektonik açıdan, kuzeyden güneye doğru Pontidler, Anatolidler, Toridler ve Kenar kıvrım kuşağı olmak üzere dört tektonik birliğe ayırmıştır. Bu çalışmanın konusu olan bölge, Torid tektonik birliğinin doğu 
kesimini oluşturan Doğu Toridler'de bulunmaktadır. Bölgede Doğu Anadolu Fay Sistemi gibi dünyanın önemli kıta içi aktif transform faylarından birinin bulunması, Keban, Maden ve Guleman'daki metalik maden yatakları ile Keban ve Karakaya barajları gibi büyük mühendislik yapılarının bulunması, bölgeyi jeolojik açıdan ilginç bir hale getirmiş ve bölgede farklı amaçlara yönelik olarak çok sayıda jeolojik çalışma yapılmıştır (Sungurlu, 1979; Şengör 1979; Perinçek ve Özkaya, 1981; Yazgan, 1984; Y1lmaz vd., 1993; Yiğitbaş ve Y1lmaz, 1996; Altunbey ve Çelik, 2005). Bu çalışmalar ile bölgenin jeolojik özellikleri, jeotektonik evrimi ve bölgedeki ekonomik değere sahip cevherleşmelerin özellikleri ortaya konulmaya çalışılmıştır.

Elazığ ve yakın çevresinde yüzeyleme veren formasyonları yaşlıdan gence doğru şu şekilde sıralamak mümkündür;

1. Keban Metamorfitleri (Geç Devoniyen-Jura)

2. Kömürhan Ofiyolitleri (Geç Kretase)

3. Elazı̆̆ Magmatitleri (Geç Kretase)

4. Harami Formasyonu (Geç KampaniyenMaastrihtiyen)
5. Hazar Grubu (Geç Kretase-Paleosen)

6. Kuşçular Formasyonu (Erken Paleosen)

7. Seske Formasyonu (Paleosen-Erken Eosen)

8. Maden Karmaşı ğ (Orta Eosen)

9. Kırkgeçit Formasyonu (Orta Eosen-Oligosen)

10. Alibonca Formasyonu (Oligosen-Erken Miyosen)

11. Karabakır Formasyonu (Pliyo-Pleistosen)

12. Alüvyonlar (Kuvaterner)

Elazığ çevresinde temel kayayı, Geç DevoniyenJura yaşlı Keban Metamorfitleri oluşturmaktadır. Bu kayaçlar en yaygın yüzeylemelerini Elazı̆̆'ın kuzey ve kuzeybatısındaki alanlarda verirler (Şekil 1). Elazığ il merkezine en yakın yüzeyleme ise Meryem Dağı ve civarındaki yüzeylemelerdir. Kaya (2014), Keban Metamorfitleri'nin mermer, fillit-klorit-serizitşist, metakonglomerametakumtaşı, kristalize kireçtaşı-kalkşist, masif dolomitik-kristalize kireçtaşı ve metaklastik (metaşeyl, kalkfillit, kalkşist) kayaçlardan meydana geldiğini ve bu metamorfik kayaçlar topluluğunun yaşını fosil bulgularına dayanarak Geç Devoniyen-Jura olarak belirtmektedir.

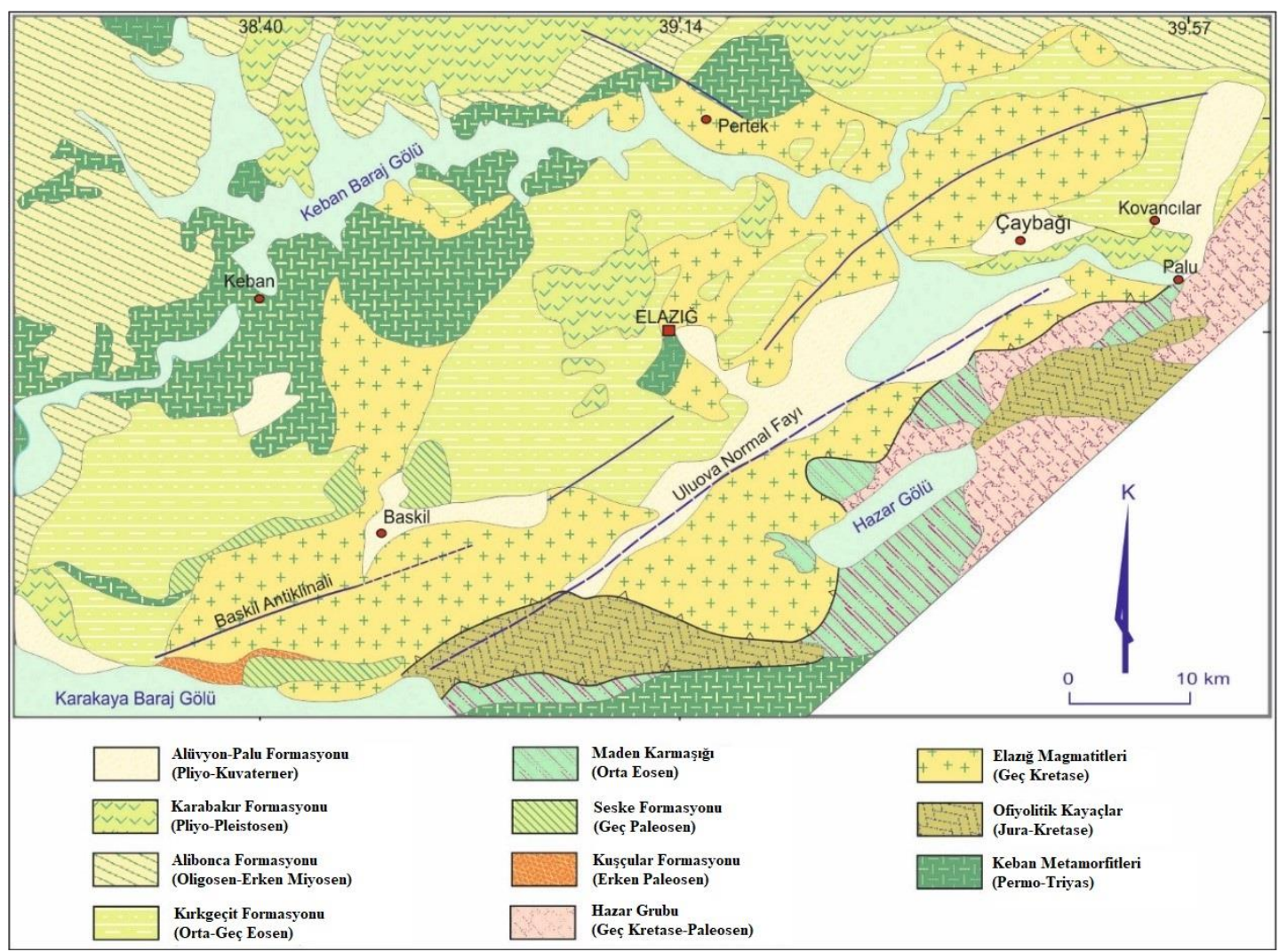

Şekil 1. Elazığ ve yakın çevresinin jeoloji haritası (Aksoy vd., 2005)

Kömürhan Ofiyolitleri, ilk defa Yazgan (1981) tarafindan adlandırmış ve sonraki çalışmalarda bu ofiyolitik kayaçlar için bu isim kullanılmıştır. Yazgan (1983), genel olarak allokton özellikteki bu ofiyolitik kayaçların Guleman Ofiyoliti'nin bat1; İspendere Ofiyoliti'nin ise doğu uzantısı olduğunu ifade etmektedir. Rızaoğlu (2006), özellikle Elazığ'ın batısında yüzeyleme veren 
(Şekil 1) Kömürhan Ofiyolitleri'nin tabandan tavana doğru tektonitler, kümülatlar, izotrop gabrolar, levha dayk kompleksi ve volkanitlerden oluştuğunu belirtmektedir.

Geç Kretase yaşlı Elazı̆̆ Magmatitleri, GD Anadolu kuşağı boyunca yaygın olarak yüzeyler ve Yüksekova Karmaşığı olarak da bilinir (Perinçek, 1979a). Kürüm ve Tany1ldızı, (2017), bu magmatik kayaçların Elazığ çevresinde gabro, diyorit ve kuvarslı diyorit bileşiminde mafik plütonik kayaçlar ve bunların eşlenikleri olan diyabaz, mikrodiyorit, kuvarsl1 mikrodiyorit, diyorit porfir gibi yarı derinlik kayaçları ile temsil edildiğini belirtmektedirler.

Geç Kretase yaşlı Harami Formasyonu, kırmızı renkli konglomeralar ile başlayıp kumtaşı ve kristalin kireçtaşlarıyla devam eden bir istif sunmaktadır (Aksoy, 1993; Özgen vd., 1993). Elazı ̆ çevresinde genellikle olistolitik kireçtaşları şeklinde ve özellikle Harput ve çevresinde yaygın bir şekilde gözlenmektedir. Ancak, formasyon çok küçük alanlarda yüzeyleme verdiğinden Şekil 1'de verilen jeoloji haritasinda bu formasyona ait yüzeylemelerin sınırları görülememektedir.

Geç Kretase-Paleosen yaşlı Hazar Grubu, Elazı̆̆ ilinin güneydoğusunda Hazar Gölü çevresi ve Palu ilçesine doğru uzanan alanlarda geniş yüzeylemeler vermektedir (Şekil 1). Aktaş ve Robertson (1984) grubu, alttan üste doğru konglomeralarla temsil edilen Ceffan Formasyonu, kumtaş1, şeyl ve marn ardalanmasından oluşan Simaki Formasyonu ve en üstte de yanal devamlılığ 1 olmayan ve kalın tabakalanmalı, gri renkli kireçtaşları ile temsil edilen Gehroz Formasyonu olmak üzere üç formasyona ayırmışlardır. Hazar Grubu'na ait kayaçlardan sadece Gehroz Formasyonu'na ait kireçtaşlarının kırmataş olabilme potansiyeli vardır. Ancak, yüzeylemelerin yerleşim alanlarına ve yol güzergahlarına çok uzak olması, ayrıca yüksek rakımlarda bulunması nedeniyle, Gehroz Formasyonu'na ait kireçtaşları bu çalışmaya dahil edilmemiştir.

Erken Plaeosen yaşlı Kuşçular Formasyonu Keban ve Baskil arasında, dar bir bölgede yüzeyleme verir ve kuzeydeki alanlardaki kayaçlardan türemiş kırmızı konglomera, kumtaşı, çamurtaşı ve evaporit litolojisindeki alüvyon yelpazesi fasiyesindedir (İbilioğlu, 2008). Formasyona ait kayaçların litolojik olarak kırmataş olabilme potansiyelinin bulunmaması nedeniyle, Kuşçular Formasyonu'na ait konglomera litolojisindeki kayaçlar bu çalışma kapsamında incelenmemiştir.

Geç Paleosen-Erken Eosen yaşlı Seske Formasyonu, Elazı̆ civarında Baskil ilçesi çevresinde ve Kömürhan Köprüsü kuzeyinde yüzeylemektedir (Şekil 1). Genellikle sığ denizel kireçtaşlarıyla temsil edilen formasyona ait kireçtaşlarının kırmataş olabilirliğini belirlemek amacıyla Kömürhan-Kuşsarayı (Baskil) yolu kireçtaşlarından örnekleme yapılmıştır.

Orta Eosen yaşlı Maden Karmaşı̆̆ı, en iyi yüzeylemelerinin görüldüğü Siirt bölgesinde tabanda konglomeratik bir istifle başlayan ve tabakalı kireçtaşı, şeyl, kumtaşı, silttaşı, kumlu kireçtaşı marn ve bunların ardalanmaları ile devam eden bir birim özelliği göstermektedir. Yazgan (1981), birim içerisinde tanımladığı ve daha sonra Perinçek (1979b) ile Erdoğan (1982) tarafindan da "üst volkanik birim" olarak adlandırılan Karadere Formasyonu'nun tüf, lapillitaşı, aglomera, alüminyumca zengin bazaltlar, dasit, mikrogranit, siyenit, diyabaz, mikrogabro gibi piroklastik-volkanik ve yarı derinlik kayaçlarından oluştuğunu ifade etmiştir. (Şekil 1).

Orta-Geç Eosen yaşlı Kırkgeçit Formasyonu, Elazı̆̆ ve yakın çevresinde oldukça yaygın yüzeylemeler verir (Şekil 1). Formasyon, tabandan tavana doğru konglomera, kumlu killi kireçtaş1, kumtaş1, şeyl, marn ve kireçtaş1 litolojisindedir (İbilioğlu, 2008).

Elazı̆g bölgesinde küçük yüzeylemeler halinde görülen Oligosen-Erken Miyosen yaşlı Alibonca Formasyonu, tabanda Kırkgeçit Formasyonu üzerine uyumsuz olarak gelir. Elazı ̆ çevresinde farklı kalınlıklarda konglomera, kumtaşı, çamurtaşı ve killi kireçtaşı litolojisindedir. Kireçtaşları sarımsı bej-kirli beyaz renkli, ortakalın tabakalanmalı olup, tabaka düzlemleri iyi gelişmemiştir. Formasyonun litolojik özellikleri kırmataş olarak kullanılmaya uygun görülmediği için, bu formasyondan örnekleme yapılmamıştır.

Pliyo-Pleistosen yaşlı Karabakır Formasyonu, Elazığ çevresinde esas olarak bazaltik bileşimli lav akıntıları ile yer yer volkanik breş ve tüf gibi piroklastik kayaçlardan oluşan bir litoloji sunar (Kürüm ve Tanyıldızı, 2017). Bölgede farklı çıkış merkezlerine bağlı olarak yerel farklılıklar sunan volkanitlerin en geniş yayılımı Cip Köyü ve kuzeye doğru olan yayılımdır ve bazaltik bileşimli bu kayaçlar alkalin özellik gösterirler (Di Giuseppe vd., 2018) (Şekil 1). 
Bölgenin en genç birimi akarsu yatakları ile ovalık kesimlerde depolanan, bölgedeki daha yaşlı kayaçlardan türemiş, blok boyutundan kil boyutuna kadar değişen boyutlarda ve çimentolanmamış malzemeden oluşan güncel alüvyonlardır (Şekil 1). Bu alüvyonlara ait bloklar farklı kökenlere sahip olduklarından ve bu yüzden kırmataş olarak kullanımları uygun olmadığından bu çalışmaya dahil edilmemiştir.

\section{Deneysel Çalışmalar}

Kaya malzemesinin kırmataş olarak kullanılabilirliği mekanik, kimyasal ve mineralojik-petrografik özelliklerinin TS, BS, ASTM gibi farkl1 standartlarda belirtilen limit değerlere uygunluğu ile mümkündür. Bu nedenle, kırmataş olarak kullanılacak kaya malzemesinin bu özelliklerini belirlenmesi ve elde edilen sonuçların standartlarda verilen sınır değerler ile karşılaştırılması gereklidir.

Bölgenin jeolojik özelliklerinin verildiği bölümde de görüleceği gibi, Elazığ ve yakın civarında farklı yaş ve litolojik özelliklere sahip 12 formasyon yüzeyleme vermektedir. $\mathrm{Bu}$ formasyonlardan bazısı litolojik olarak kırmataş olmaya uygun olmadığından, bazı formasyonlar da yerleşim ve yol güzergahlarına çok uzak alanlarda yüzeyleme verdiğinden dolayı bu formasyonlardan örnekleme yapılmıştır. Yapılan ön değerlendirme sonrasında Keban Metamorfitleri'ne ait kristalize kireçtaşları (1), Kömürhan Ofiyolitleri'ne ait gabrolar (2), Elazı̆̆ Magmatitleri'ne ait granitler (3) ve andezitler (4), Harami Formasyonu'na ait kireçtaşları (5), Seske Formasyonu'na ait kireçtaşları (6), Maden Karmaşı̆̆ı'na ait bazaltlar (7), Kırkgeçit Formasyonu'na ait kireçtaşları (8) ve Karabakır Formasyonu'na ait bazaltların (9) kırmataş olarak kullanılabilecekleri sonucuna varılmıştır. $\mathrm{Bu}$ formasyonlardan derlenen blok örneklerden hazırlanan agrega örneklerinin fiziksel, mekanik, kimyasal ve mineralojik-petrografik özelliklerini belirlenmek amaciyla laboratuvar deneyleri yapılmıştır. TS 706 EN 12620 (2009) standardında yapılması önerilen deneyler ve bu deneylere ait standartlar Tablo 1'de verilmiştir.

Tablo 1. Yapılan deneyler ve ilgili standartlar

\begin{tabular}{ll}
\hline DENEYLER & STANDARTLAR \\
\hline Kuru Özgül Ağırlık & \\
$\begin{array}{l}\text { Doygun Özgül Ağırlık (yüzey kuru) } \\
\text { Görünür Özgül Ağıllık }\end{array}$ & TS EN 1097-6 (2013) \\
Su emme & \\
İnce madde oranı & TS EN 933-10 (2010) \\
Çok ince madde oranı & TS EN 1367-2 (2010) \\
MgSO çözeltisinde don kaybı & TS EN 1097-2 (2016) \\
Los Angeles parçalanma dayanımı & TS EN 1097-1 (2011) \\
Mikro-deval aşınma dayanımı & CSA A23.2-25A (2014) \\
Alkali-Silika reaktivitesi & TS EN 933-4 (2009) \\
Şekil endeksi & TS EN 933-3 (2012) \\
Yassılık endeksi & TS EN 1097-3 (1999) \\
Gevşek yığın yoğunluğu & TS EN 933-9 (2014) \\
Metilen mavisi deneyi & \\
Ana oksit yüzdeleri & \\
Asitte çözünebilen sülfat miktarı & TS EN 1744-1 (2013) \\
Suda çözünebilen klorür miktarı & \\
Toplam kükürt miktarı & \\
Mineralojik ve petrografik analiz & TS 10088 EN 932-3 (2006) \\
\hline
\end{tabular}

Tablo 1'de verilen standartlara göre gerçekleştirilen fiziksel, mekanik ve kimyasal deneylere ait sonuçlar Tablo 2 ve 3 'de, petrografik incelemelere ait değerlendirmeler ise Tablo 4'de sunulmuştur.

İncelenen kayaçların mineralojik ve petrografik özelliklerini belirlemek amaciyla, F.Ü. Jeoloji Müjhendisliği İnce Kesit Laboratuvarı'nda ince kesitler hazırlanmıştır. İnce kesitlerde TS 10088 EN 932-3 (2006) standardına uygun olarak mikroskopik çalışmalar yapılmış ve sedimanter kayaçlar Dunhum (1962) sinıflamasına, magmatik kayaçlar ise Streckeisen (1976) tarafindan önerilen QAPF diyagramı kullanılarak sınıflandırılmıştır. Yapılan petrografik çalışmalara ait sonuçlar aşağıda özetlenmiştir. 
Tablo 2. Agrega örneklerinin fiziksel ve mekanik özelliklerine ait ortalama değerler

\begin{tabular}{|c|c|c|c|c|c|c|c|c|c|}
\hline DENEYLER & 1 & 2 & 3 & 4 & 5 & 6 & 7 & 8 & 9 \\
\hline Kuru Özgül Ağırlık & 2.61 & 2.89 & 2.49 & 2.75 & 2.67 & 2.66 & 2.82 & 2.64 & 2.66 \\
\hline Yüzey Kuru Doygun Özgül Ağırlık & 2.63 & 2.90 & 2.55 & 2.78 & 2.69 & 2.68 & 2.84 & 2.66 & 2.68 \\
\hline Görünür Özgül Ağırlık & 2.67 & 2.93 & 2.63 & 2.84 & 2.71 & 2.73 & 2.89 & 2.71 & 2.72 \\
\hline Su Emme Oranı, (\%) & 0.88 & 0.52 & 2.10 & 1.16 & 0.64 & 0.95 & 0.96 & 1.09 & 1.84 \\
\hline Y1kanabilen İnce Madde oranı (\%) & 0.92 & 0.41 & 1.28 & 0.59 & 0.45 & 0.14 & 0.31 & 0.96 & 1.52 \\
\hline İnce Madde oranı $(\%)$ (0.5 mm altı) & 0.52 & 1.18 & 3.78 & 1.04 & 1.66 & 0.95 & 1.02 & 2.13 & 2.64 \\
\hline Yassıllk Endeksi (\%) & 2 & 19 & 7 & 5 & 11 & 7 & 5 & 2 & 1 \\
\hline Şekil Endeksi (\%) & 11 & 12 & 37 & 17 & 6 & 10 & 8 & 6 & 9 \\
\hline Gevşsek Yığın Yoğunluğu (kg/dm³ & 1.63 & 1.74 & 1.55 & 1.73 & 1.68 & 1.67 & 1.79 & 1.65 & 1.51 \\
\hline Metilen Mavisi (MB) & 0.50 & 1.25 & 3.10 & 1.60 & 0.75 & 0.55 & 0.85 & 0.50 & 2.50 \\
\hline $\begin{array}{l}\text { Los Angeles Parçalanma Dayanımı } \\
\text { (LA) }\end{array}$ & 24 & 16 & 51 & 9 & 21 & 20 & 8 & 23 & 14 \\
\hline Mikro-Deval Aşınma dayanımı (MDE) & 27 & 15 & 20 & 15 & 17 & 10 & 11 & 18 & 13 \\
\hline $\mathrm{MgSO}_{4}$ Çözeltisinde Don Kaybı (\%) & 9.96 & 19.92 & 45.17 & 15.32 & 7.20 & 8.24 & 9.19 & 6.80 & 16.27 \\
\hline $\begin{array}{l}\text { Alkali-Silika Reaktivitesi } \\
\text { (14 günlük genleşme, } \%)\end{array}$ & 0.040 & 0.134 & 0.073 & 0.142 & 0.012 & 0.015 & 0.135 & 0.014 & 0.025 \\
\hline
\end{tabular}

Tablo 3. Agrega örneklerinin kimyasal özellikleri

\begin{tabular}{lccccccccc}
\hline ANA OKSİT (\%) & $\mathbf{1}$ & $\mathbf{2}$ & $\mathbf{3}$ & $\mathbf{4}$ & $\mathbf{5}$ & $\mathbf{6}$ & $\mathbf{7}$ & $\mathbf{8}$ & $\mathbf{9}$ \\
\hline $\mathrm{SiO} 2$ & 1.50 & 37.10 & 61.6 & 41.70 & 2.70 & 0.90 & 43.10 & 0.50 & 47.20 \\
$\mathrm{CaO}$ & 5.50 & 16.10 & 2.6 & 15.20 & 53.10 & 54.80 & 10.20 & 56.20 & 9.00 \\
$\mathrm{Al2O} 3$ & 0.20 & 14.50 & 18.1 & 14.70 & 1.20 & 0.40 & 17.30 & 0.20 & 19.60 \\
$\mathrm{Fe} 2 \mathrm{O} 3$ & 0.20 & 13.00 & 4.8 & 9.80 & 1.00 & 0.40 & 10.20 & 0.10 & 8.70 \\
$\mathrm{MgO}$ & 0.80 & 6.30 & 1.1 & 3.90 & 0.70 & 0.50 & 8.00 & 0.30 & 4.20 \\
$\mathrm{Na} 2 \mathrm{O}$ & 0.20 & 2.00 & 5.4 & 3.00 & 0.30 & 0.20 & 2.60 & 0.20 & 4.70 \\
$\mathrm{P} 2 \mathrm{O} 5$ & $<0.10$ & 0.40 & 0.1 & 0.10 & $<0.10$ & $<0.10$ & 0.20 & $<0.10$ & 0.80 \\
$\mathrm{~K} 2 \mathrm{O}$ & $<0.10$ & 0.50 & 3.4 & 0.60 & 0.10 & $<0.10$ & 1.00 & $<0.10$ & 2.10 \\
$\mathrm{Tio2}$ & $<0.10$ & 1.10 & 0.6 & 0.80 & 0.10 & $<0.10$ & 0.90 & $<0.10$ & 1.70 \\
$\mathrm{MnO}$ & $<0.10$ & 0.30 & 0.1 & 0.20 & $<0.10$ & $<0.10$ & 0.20 & $<0.10$ & 0.20 \\
$\mathrm{Ateş} \mathrm{Kayb1}$ & 42.05 & 8.30 & 1.85 & 9.65 & 40.70 & 42.50 & 6.25 & 42.40 & 1.50 \\
$\mathrm{Suda}$ Çözünebilen Klorür (\%) & 0.0033 & 0.0073 & 0.0041 & 0.0031 & 0.0032 & 0.0012 & 0.0011 & 0.0030 & 0.0036 \\
Asitte Çözünebilen Sülfat (\%) & 0.09 & 0.07 & 0.14 & 0.07 & 0.07 & 0.27 & 0.06 & 0.08 & 0.05 \\
Toplam Kükürt (\%) & 0.11 & 0.10 & 0.14 & 0.08 & 0.08 & 0.12 & 0.03 & 0.09 & 0.05 \\
\hline
\end{tabular}

Keban Metamorfitleri: Kayaç esas olarak öz ve yarı öz şekilli açık bej-kirli beyaz renkli kalsit, klorit, serizit ve kuvars minerallerinden oluşmaktadır. Klorit ve serizitler lepidoblastik dokudadır ve kink-bant yapısı göstermektedir. Kuvars kristallerinde ise dalgalı sönmeler mevcuttur. Kayaç re-kristalize kireçtaşı olarak tanımlanmıştır.

Kömürhan Ofiyolitleri: Genel olarak \%90'dan fazla oranda Labrador türü plajiyokalslardan oluşan kayaçta, labradorlar öz-yarı öz şekilli ortairi taneli, hem albit hem de polisentetik ikizlenmeleri gösterirler. Metamorfizma etisiyle gelişmiş deformasyonlar ile kısmen serizitleşme ve killeşme belirlenmiştir. İri taneli poikilitik doku gösteren hornblend mineralleri yer yer aktinolit-tremolite dönüşmüştür. Kayaç ikincil mineral olarak kalsit, silis ve klorit içermektedir. Kayaç gabro olarak tanımlanmıştır.

Elazığ Magmatitleri: Bu magmatit kayaçlardan derlenen ilk örnek; \%50-60 oranında plajiyoklas, \%20-30 oranında kuvars, \%30-40 oranında potasyum feldspat, ayrica az miktarlarda amfibolit, apatit ve opak minerallerden oluşmaktadır. Plajiyoklaslar Albit ikizlenmeleri göstermektedir. Kuvarslar faklı boyutlardadır ve dalgalı sönme gösterirler. Amfibollerde kloritleşme görülmektedir. Kayaç granit olarak tanımlanmıştır.

Aynı magmatitlerden derlenen diğer örnekte yapılan ince kesit çalışmalarında, kayacın genel olarak \%90'dan fazla oranda plajiyoklas, az oranlarda ise hornblend, biyotit ve cams1 malzemeden oluştuğu ve porfirik dokulu olduğu belirlenmiştir. Ayrışma tipi olarak kloritleşme gözlenmektedir. Kayaç andezit olarak tanımlanmıştır.

Harami Formasyonu: Kayaç esas olarak sparitik çimentolu yarı öz şekilli kalsit kristallerinden oluşmaktadır. Az olarak ekstraklastlar da görülmektedir. Taneler arası boşlukları sparit çimento doldurmuş durumdadır. Kayaç rudist ve mercan parçacıkları içermektedir. Kayaç tanetaşı (kireçtaşı) olarak tanımlanmıştır.

Seske Formasyonu: Esas olarak yarı öz şekilli birincil kalsit ve ikincil kalsit kristallerinden 
oluşan kayaçta çimento büyük oranda karbonat çumurudur. Kayaç bol miktarda fosil de içermektedir. Kayaç istiftaşı (kireçtaşı) olarak tanımlanmıştır.

Maden Karmaşı̆̆ı: Kayaç esas olarak (>\%90) camsı malzeme ve plajiyoklas mikrolitlerinden oluşan hamur içerisindeki labrador ve ojit fenokristallerinden oluşmaktadır. Vitroporfirik ve amigdaloidal dokulu kayacin amigdalleri klorit, kalsit ve zeolit gibi ikincil mineraller tarafindan doldurulmuştur. Kayaç bazalt olarak tanımlanmıştır.

Kırkgeçit Formasyonu: Esas olarak kalsit kristallerinin oluşturduğu kayaçta, bu kalsit kristalleri sparit çimento ile birbirine bağlanmıştır. Kayaç içerisinde iri kuvars taneleri ve bol miktarda fosil, az olarak da kayaç parçacıkları gözlenmektedir. Kayaç bağlamtaşı (kireçtaşı) olarak tanımlanmıştır.

Karabakır Formasyonu: Kayaç \%90-94 oranında plajyoklaslardan az oranlarda ise olivin, piroksen ve amfibolden oluşmaktadır. Ayrıca alterasyon sonucu oluşan iddingsit ve karbonat mineralleri ile gaz boşluklarını dolduran kalsit ve epidot gibi ikincil minerallere de görülmektedir. Plajyoklaslar genellikle uzamış küçük prizmatik latalar ve mikrolitler halindedir. Olivinler fenokristal boyutundan mikrolit boyutuna kadar değişen kristaller halinde ve genelde öz şekilli veya yarı öz şekilli olarak bulunurlar ve iddingsitleşmiştir. Piroksenler ise genellikle fenokristaller halindedir ve hamur içerisinde mikrolitler halinde olanları da mevcuttur. Kayaç bazalt olarak tanımlanmıştır.

\section{Laboratuvar Sonuçlarının Değerlendirilmesi}

Elazı̆̆ ve yakın çevresinde kırmataş olabilme potansiyeline sahip kayaçlardan derlenen bloklardan hazırlanan agrega örneklerinde gerçekleştirilen laboratuvar deney sonuçları değerlendirilerek, bu kayaçların betonda ve asfalt karışımında agrega, demiryollarında balast ve karayollarında alttemel malzemesi olarak kullanılabilirliğini belirlenmeye çalışılmıştır.

\subsection{Kayaçların Beton Agregası Olabilirliği}

Beton karışımının yaklaşık olarak \%70'ini oluşturan agrega (Şekil 2), hazır beton üretiminde ekonomi ve dayanım yönünden önemli bir işleve sahiptir. Nitekim, agreganın maliyeti çimentoya nazaran daha düşük olduğu için, beton üretiminde kullanılan ve maliyeti düşük olan bir yap1 malzemesi olarak kabul görmektedir. Ancak, kayaçların agrega olarak değerlendirilebilmeleri için belli özelliklere sahip olması gereklidir.

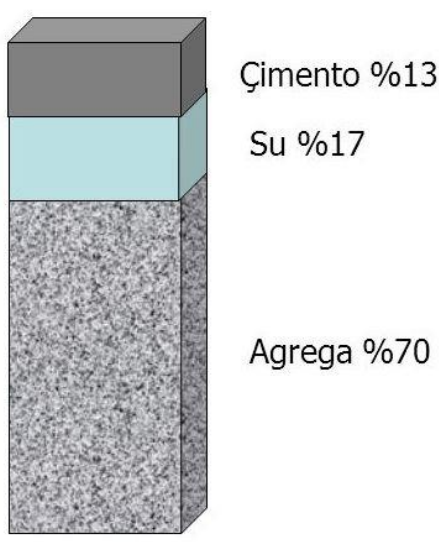

Şekil 2. Beton bileşenleri ve yaklaşık hacimce yüzdeleri

Postacıoğlu (1987), kırmataşlardan elde edilen agregaların yüzeylerinin dere malzemesine nazaran daha pürüzlü olması sebebiyle çimento hamuru ile agrega arasında daha sağlıklı bir bağ ortaya çıktığını, pürüzlü kısımların büyük olması, kırmataş agrega ile çimento hamurunun temas yüzeyinin de o kadar geniş olmasını sağladığını belirtmektedir. Araştırmacı, bu sebepten ötürü kırmataş agrega ile üretilen betonlarda dayanımların arttığını ve agrega danelerinin nispeten kübik veya küre şekline yakın olmasının, daha kaliteli bir beton üretimi için büyük önem arz ettiğini ifade etmektedir.

Cilason (1992), beton üretiminde agrega kullanımının, sertleşen betonun hacimsel değişikliklerini azalttığını, çevresel etkilere karşı betonun dayanımını artırdığını ve üretilen betonda istenilen dayanımın elde edilmesinde öncü bir görev üstlendiğini belirtmektedir.

Giaccio vd. (1992) ise granit, bazalt ve kireçtaş1 agregası kullanılarak elde edilen betonlar üzerinde basınç testi, elastisite modülü, çekme dayanımı ve eğilme testleri yaparak betonun iç bağındaki çözülmeleri ve süreksizlik sınırlarını inceledikleri araştırmalarında, takip betonun iç bağında meydana gelen bozulmaların nedeninin, agreganın sıkıştırılmasına, temizliğine, karışımına ve agrega türüne göre farkl1lık gösterdiğini, süreksizlik sınırının ise agreganın cinsine bağlı olarak bir farklı1ık göstermediğini belirtmişlerdir. $\mathrm{Bu}$ araştırmada ayrıca, daha sert kayaçlardan elde edilen agregaların kullanıldığı betonun dayanım değerlerinin de yüksek çıktığı ifade edilmektedir. 
Alexander ve Milne (1995), dört farklı agrega tipi kullanılarak elde edilen beton numunelerinde, agrega ile çimento geçiş bölgelerinin, agreganın doğal ve mineral yapısına bağlı olarak değişiklikler gösterdiğini belirtmişlerdir.

Tasong vd. (1998), farklı mineral yapısına sahip agregalar arasinda ciddi farklılıklar tespit edildiğini ifade ederek, kayaç yapısının ve kimyasal reaksiyonların betonun dayanımında önemli bir parametre olarak ele alınması gerektiğini belirtmişlerdir.

Yeğinobalı (1999), yüzeyi pürüzlü ve nispeten köşeli agregaların yuvarlak daneli agregalara göre çimento karışımı ile daha sağlıklı bir bağ oluşturabildiğini, agrega yüzeyinin gözenekli olması halinde ise çimento karışımının bu bağı daha da sağlamlaştırdığını, agreganın mineralojik yapısının da oluşacak bu aderansa etkisinin büyük olduğunu belirtmektedir.

Şimşek (2003), kaliteli bir beton üretimi için agregalarda bulunması gereken koşulları şu şekilde vermektedir;

a) Agregalar sağlam olmalı, aşınmamalı, suyun etkisiyle yumuşamamalı ve dağılmamalıdır.

b) Çimento bileşenleriyle zararlı bileşikler meydana getirmemeli ve donatının korozyona karşı korunmasını tehlikeye düşürmemelidir.

c) Danelerin biçimi, dokusu iyi olmalıdır.

d) Danelerin büyüklük bakımından dağılımı, amaca ve standartlara uygun olmalıdir.

e) Agrega içinde betona zarar verecek maddeler bulunmamalıdır.

Baska (2006) ise yapı tasarımı yapılırken inşa esnasında kullanılacak betonun basınç değerinin önemli bir tasarım parametresi olduğunu ve betonarme elemanlarda betonun basinç dayanımının o elemanın taşıma gücünü doğrudan etkilediğini belirtmektedir.

Agregaların ekonomik ve dayanımlı olmaları, beton yapımında kullanılabilmeleri için en önemli etkenler olarak sıralanmaktadır. Agrega, betonun dayanımı ile beraber, davranışını da direkt olarak etkilemektedir. Betonun kısa veya uzun süreli performansında agrega ile çimento harc1 arasındaki aderansın da etkisi yok sayılamayacak kadar önemlidir. Agrega granülometrisinin uygun olması halinde, karışım hazırlanırken daha az çimentoya ihtiyaç duyulacağı bilinmektedir. Diğer yandan, beton üretiminde kullanılan agreganın dane şekli, mineral yapısı, dane dağılımı, aşınma dayanımı, don dayanımı, özgül ağırlığı, birim hacim ağırlığı, su emmesi, boşluk oranı, sertliği ve kimyasal etkilere karşı dayanımı üretilecek betonun dayanımını direkt olarak etkileyen önemli parametreler olarak karşımıza çıkmaktadır (Erdoğan, 1995).

Kayaçların beton agregası olarak kullanılabilirliği, bu kayaçlardan elde edilen agrega örneklerinin bazı fiziksel, mekanik ve kimyasal özelliklerini belli limit değerlere uygunluğu ile mümkündür. Kayaçların beton agregası olarak kullanılabilirliği Tablo 4'te değerlendirilmiştir.

Yapılan değerlendirmelere göre, Keban Metamorfitleri'ne ait rekristalize kireçtaşlarının (1) fiziksel ve kimyasal özellikleri beton agregası olarak kullanılabilmeye uygundur. Ancak, bu kayaçların Los Angeles parçalanma dayanımı değeri limitler içerisinde olmasına rağmen az da olsa düşüktür $\left(\mathrm{LA}_{24}\right)$. Ayrıca, tüm birimler arasında Mikro-Deval aşınma dayanımı en az olan birim bu re-kristalize kireçtaşlarıdır ve MikroDeval aşınma kaybı değeri TS EN 1097-1 (2011) standardında belirlenen $\mathrm{MDE}_{25}$ sınır değerinin üstündedir. $\mathrm{Bu}$ nedenle aşınmaya maruz kalabilecek alanlarda kullanılmasindan kaçınılması gerekmektedir.

Kömürhan Ofiyolitleri'ne ait gabroların (2) $\mathrm{MgSO}_{4}$ çözeltisinde don kaybı değeri \%19.92 olarak belirlenmiştir. Bu değer TS EN 1367-2 (2010)'da verilen limit değerin az da olsa üstündedir. Ayrıca, birime ait agregaların yassılık endeksi değeri de \%19'dur ve TS EN 933-3 (2012)'de verilen üst sınır değere çok yakındır. Birimin 14 günlük Alkali-Silika reaktivitesi genleşme değeri (\% 0.134) limit değerlerin altında olmasına karşın, 28 günlük genleşme değeri \% 0.314 olarak belirlenmiştir. Bu genleşme değeri, Alkali-Silika reaktivitesinin meydana gelmesi açısından oldukça riskli bir duruma işaret etmektedir. $\mathrm{Bu}$ veriler 1şı̆̆ında, Kömürhan Ofiyolitleri'ne ait gabroların beton üretiminde kullanılmasından kaçınılması gerekmektedir.

Elazığ Magmatitleri'ne ait granitlere (3) ait sonuçlar bu kayaçların beton üretiminde kesinlikle kullanılmaması gerektiğini göstermektedir. Nitekim, granitlerin Metilen Mavisi değeri 3.10 olarak belirlenmiş ve sınır değer olarak verilen 2.00 değerinden çok yüksektir. Ayrıca, Los Angeles parçalanma dayanımı $\mathrm{LA}_{51}$ ve $\mathrm{MgSO}_{4}$ çözeltisinde don kaybı ise \% 45.17 olarak belirlenmiştir. Granitlere ait şekil endeksi değeri \%37 dir ve tüm birimler içerisinde en yüksek şekil endeksi değeridir. Micro-Deval aşınma dayanımı da $\mathrm{MDE}_{20}$ olarak belirlenmiş ve üst sınır değere çok yakındır. Sonuç olarak, bu granitlerden elde 
edilecek agregaların beton imalatında kullanılması mümkün değildir.

Seske Formasyonu'na ait kireçtaşlarına (6) ait sonuçlara göre, bu kireçtaşlarının asitte çözünebilen sülfat oranı $\% \quad 0.27$ olarak belirlenmiştir. Bu değer TS EN 1744-1 (2013) standardında önerilen \% 0.20 üst limit değerinden yüksektir. Sülfat, çimentonun hidrate bileşenleri olan Kalsiyum Hidroksit $\mathrm{Ca}(\mathrm{OH})_{2}$ ve Trikalsiyum Alüminat $\left(\mathrm{C}_{3} \mathrm{~A}\right)$ ile tepkimeye girerek etrenjit ve alçı taşı oluşumuna neden olurlar. $\mathrm{Bu}$ reaksiyon ürünleri betonda genleşmeye, dolayısıyla çatlaklara ve dağılmaya neden olur. Meydana gelen bu olaylar sonucunda agrega-çimento aderansının etkilenmesiyle betonun dayanımı önemli ölçüde azalır. Seske Formasyonu'na ait kireçtaşlarında sülfat miktarının yüksekliği, bu kireçtaşlarının içerdiği evaporitik seviyelerden kaynaklanabilir. $\mathrm{Bu}$ nedenle, bu kireçtaşlarının agrega olarak kullanımında dikkatli davranmak gerekir. Agreganın içerdiği sülfat oranının değişiklik gösterebileceği unutulmamalı ve belli aralıklarla sülfat tayini yapılarak bu değerin aşırı yükselmesi durumunda bu kireçtaşları agrega olarak kullanılmamalıdır.

Tablo 4. Agrega örneklerinin beton agregası olarak kullanılabilirliği

\begin{tabular}{|c|c|c|c|c|c|c|c|c|c|c|}
\hline DENEYLER & $\begin{array}{l}\text { Standartlar ve } \\
\text { sınır değerler }\end{array}$ & 1 & 2 & 3 & 4 & 5 & 6 & 7 & 8 & 9 \\
\hline $\begin{array}{l}\text { Yüzey Kuru } \\
\text { Özgül Ağırlık }\end{array}$ & $\begin{array}{l}\text { TS EN 1097-6 } \\
\geq 2.55\end{array}$ & 2.63 & 2.90 & 2.55 & 2.78 & 2.69 & 2.68 & 2.84 & 2.66 & 2.68 \\
\hline Su Emme oranı, (\%) & $\begin{array}{l}\text { TS EN 1097-6 } \\
<\% 3.0\end{array}$ & 0.88 & 0.52 & 2.10 & 1.16 & 0.64 & 0.95 & 0.96 & 1.09 & 1.84 \\
\hline $\begin{array}{l}\text { Çok İnce Madde oranı (\%) } \\
(0.063 \mathrm{~mm} \text { altı) }\end{array}$ & $\begin{array}{c}\text { TS EN 933-10 } \\
<\% 5\end{array}$ & 0.92 & 0.41 & 1.28 & 0.59 & 0.45 & 0.14 & 0.31 & 0.96 & 1.52 \\
\hline $\begin{array}{l}\text { İnce Madde oranı }(\%)(0.5 \\
\text { mm altı) }\end{array}$ & $\begin{array}{c}\text { TS EN 933-10 } \\
<\% 5\end{array}$ & 0.52 & 1.18 & 3.78 & 1.04 & 1.66 & 0.95 & 1.02 & 2.13 & 2.64 \\
\hline Yassıllk Endeksi (\%) & $\begin{array}{l}\text { TS EN 933-3 } \\
\leq \% 20\end{array}$ & 2 & 19 & 7 & 5 & 11 & 7 & 5 & 2 & 1 \\
\hline Şekil Endeksi (\%) & $\begin{array}{l}\text { TS EN } 933-4 \\
\leq \% 55\end{array}$ & 11 & 12 & 37 & 17 & 6 & 10 & 8 & 6 & 9 \\
\hline $\begin{array}{l}\text { Gevşek Yığın Yoğunluğu } \\
\left(\mathrm{kg} / \mathrm{dm}^{3}\right)\end{array}$ & $\begin{array}{c}\text { TS EN 1097-3 } \\
1.5-1.9\end{array}$ & 1.63 & 1.74 & 1.55 & 1.73 & 1.68 & 1.67 & 1.79 & 1.65 & 1.51 \\
\hline Metilen Mavisi & $\begin{array}{c}\text { TS EN 933-9 } \\
\text { (kireçtaş1 } \leq 1.5) \\
(\text { magmatik } \leq 2.0)\end{array}$ & 0.50 & 1.25 & 3.10 & 1.60 & 0.75 & 0.55 & 0.85 & 0.50 & 2.50 \\
\hline $\begin{array}{l}\text { Los Angeles Parçalanma } \\
\text { Dayanımı (LA) }\end{array}$ & $\begin{array}{l}\text { TS EN 1097-2/D1 } \\
\text { LA }_{30}(\leq 30)\end{array}$ & 24 & 16 & 51 & 9 & 21 & 20 & 8 & 23 & 14 \\
\hline $\begin{array}{l}\text { Mikro-Deval Aşınma } \\
\text { dayanımı (MDE) }\end{array}$ & $\begin{array}{l}\text { TS EN 1097-1 } \\
\operatorname{MDE}_{25}(\leq 25)\end{array}$ & 27 & 15 & 20 & 15 & 17 & 10 & 11 & 18 & 13 \\
\hline $\begin{array}{l}\mathrm{MgSO}_{4} \text { Çözeltisinde Don } \\
\text { Kaybı (\%) }\end{array}$ & $\begin{array}{l}\text { TS EN } 1367-2 \\
\leq \% 18\end{array}$ & 9.96 & 19.92 & 45.17 & 15.32 & 7.20 & 8.24 & 9.19 & 6.80 & 16.27 \\
\hline $\begin{array}{l}\text { Alkali-Silika Reaktivitesi } \\
(\%)\end{array}$ & $\begin{array}{c}\text { CSA A23.2-25A } \\
<\% 0.15 \\
\text { (14 günlük })\end{array}$ & 0.040 & 0.134 & 0.073 & 0.142 & 0.012 & 0.015 & 0.135 & 0.014 & 0.025 \\
\hline Suda Çözünebilen Klorür & $\begin{array}{c}\text { TS EN 1744-1 } \\
<\% 0.04\end{array}$ & 0.0033 & 0.0073 & 0.0041 & 0.0031 & 0.0032 & 0.0012 & 0.0011 & 0.0030 & 0.0036 \\
\hline Asitte Çözünebilen Sülfat & $\begin{array}{c}\text { TS EN 1744-1 } \\
<\% 0.2\end{array}$ & 0.09 & 0.07 & 0.14 & 0.07 & 0.07 & 0.27 & 0.06 & 0.08 & 0.05 \\
\hline Toplam Kükürt & $\begin{array}{c}\text { TS EN 1744-1 } \\
<\% 1.0\end{array}$ & 0.11 & 0.10 & 0.14 & 0.08 & 0.08 & 0.12 & 0.03 & 0.09 & 0.05 \\
\hline
\end{tabular}

Not: Gri alanlardaki değerler standartlara uygun olan değerleri göstermektedir.

Elazı ̆̆ Bölgesi’nde yüzeyleyen kayaçlardan beton agregas1 olarak kullanılmaya uygun olmadığ belirlenen son birim ise Karabakır Formasyonu'na ait bazaltlardır (9). Bu bazaltlar halen yoğun bir şekilde hazır beton üretiminde kullanılmasına karşın, metilen mavisi deneyi sonucunda bazaltların (MB) değeri 2.50 olarak belirlenmiştir. Ancak, TS EN 933-9 (2014) standardında magmatik kökenli kayaçlarda bu değerin en fazla 2.00 olması gerektiği belirtilmektedir. MB değerinin yüksek olması, agregada çok ince malzeme miktarının fazla olduğu, yani agreganın kirli olduğu anlamına gelmektedir. Ayrıca, bu bazaltların $\mathrm{MgSO}_{4}$ çözeltisinde don kaybı değeri ise \%16.27'dir ve bu değer TS EN 1367-2 (2010)'da verilen limit değer olan \%18 değerine çok yakındır. Karabakır Formasyonu'na ait bazaltlarda Metilen mavisi ve $\mathrm{MgSO}_{4}$ çözeltisinde don kaybı değerlerinin yüksek çıkmasının nedeni, bu bazaltların yoğun miktarda gaz boşlukları 
bulundurması ve bu boşlukların ikincil mineraller içermesinden kaynaklanmaktadır. $\mathrm{Bu}$ ikincil mineraller agreganın Metilen mavisi (MB) değerinde artışa, boşluklar ise kayacın dona karşı dayanımında azalmaya neden olmaktadır. Bu sebeple, bazaltların agrega olarak kullanımında dikkatli olunması, kırıcıdan geçen agreganın çok iyi yıkanması ve agrega üretiminde bu formasyona ait boşluksuz bazaltların seçimine özen gösterilmesi gerekmektedir.

Elazığ bölgesinde yüzeyleme veren Elazı̆̆ Magmatitleri'ne ait andezitler (4), Harami Formasyonu'na ait kireçtaşları (5), Maden Karmaşığı'na ait bazaltlar (7) ve Kırkgeçit Formasyonu'na ait kireçtaşlarının (8) tüm fiziksel ve kimyasal özellikleri, bu birimlerden elde edilecek olan agreganın beton üretiminde kullanılması açısından herhangi bir sakınca olmadığını göstermektedir.

\subsection{Kayaçların Balast Olabilirliği}

Günümüzde hızla artan sadece hazır beton imalatı için gerek duyulan agrega ihtiyacı değildir. Artan ulaşım talebini karşılayabilmek yeni hızlı tren projeleri balasta olan talebin de hılı bir şekilde artmasına neden olmuştur. Şekil 3'de verilen tipik bir raylı sistem kesitinde, rayları taşıyan traverslerin üzerinde yer aldığı balast, ray ve travers gibi üst yap1 elemanlarına istenen esneklikte mesnetlik ederek yol yatağının duraylılığının sağlanması, dingil yüklerinden kaynaklanan normal gerilmelerin alt katmanlara yayılarak azaltılması, yüzey sularının drene edilmesi, tren titreşimlerini sönümlendirilmesi ve yeterli elektrik yalıtımının sağlanması amacıyla demiryolu güzergahına serilen malzeme olarak tanımlanır (Arıoğlu vd., 2009).

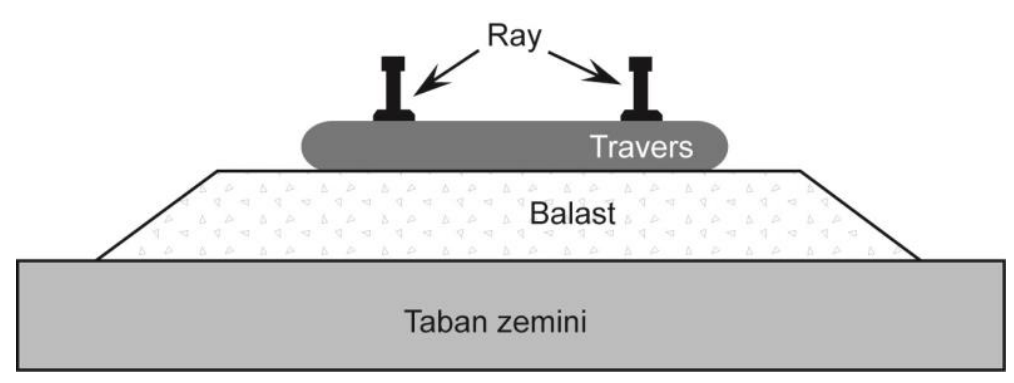

Şekil 3. Balastlı demiryolu en kesiti (Y1lmaz, 2015)

Huang (2010)'a göre, genel olarak $31.50 \mathrm{~mm}$ ile $63.00 \mathrm{~mm}$ çapındaki köşeli olan balastın elde edildiği kayacın türü, şekli, dona, aşınmaya ve parçalanmaya karşı dayanımı yukarıda verilen amaçları sağlayabilmesi açısından önem taşımaktadır.

Selig ve Waters (1994), karakteristik olarak, köşeli, kırılmış, uniform derecelenmiş, toz ve kirden arındırılmış ve çimentolanma davranışı göstermeyen sert kayaçların iyi balast malzemesi olabileceğini belirterek, kayacın balast olarak kullanılabilirliği ve ekonomik oluşunun balast malzemesinin seçiminde dikkate alınan başlıca faktörler olduğunu ifade etmektedirler. Araştırmacılar, balastın en önemli işlevlerini şu şekilde sıralamaktadırlar;

a) Yolu istenen konumda tutarak traverslere uygulanan düşey (kaldırma kuvveti dahil), yanal ve boyuna kuvvetlere karşı koymak,

b) Yola esneklik vermek ve enerji emilimini sağlamak,

c) Balast içindeki kirli malzemenin depolanması için büyük boşluklar oluşturmak ve balast boyunca parçacıkların hareketini sağlamak, d) Buraj makinesi ile balast parçacıklarının yeniden düzenlenmesi sayesinde yüzey ve tabaka işlemlerinin bakımını kolaylaştırmak,

e) Yol üzerine düşen suyun anında drenajını sağlamak,

f) Gerilmeleri alttaki malzeme için kabul edilebilir seviyelere indirgemektir.

Adam vd. (2010) ise balastın yoğun ve düzgün sıkıştırılmasının, dinamik trafik yükleri sonucunda oluşan bozulmaları önlemek için gerekli olduğunu, bunun için teorik tasarım modelleri, geniş kapsamlı testler ve yerinde yapılan ölçümlerle doğrulama gerektiğini belirtmektedirler.

Türk Standartları Enstitüsü (TSE) tarafından önerilen standartlardan TS 7043 EN 13450 (2004) standardı, kayaçların demiryolu balastı olarak kullanabilirliği ile ilgilidir. Ülkemizde demiryollarında kullanılacak olan balast malzemesinin hangi özelliklere sahip olması gerektiği TCDD Teknik Şartnamesi (2017)'de belirtilmektedir. $\mathrm{Bu}$ şartnameye göre, balast olarak kullanılacak kaya malzemesinin 
özelliklerinin $\quad$ TS 7043 EN $13450 \quad$ (2004) standardına uygun olması gerekmektedir. Ayrıca, mineralojik ve petrografik incelemeler sonucunda bazalt, granit, granadiyorit, diyorit, gabro, riyolit, ve diyabaz gibi magmatik kökenli, daha çok bazik karakterli derinlik, yarı derinlik ve yüzey kayaçlarının balast olarak uygun olduğunu belirtmektedir. $\mathrm{Bu}$ nedenle, öncelikle Elazığ bölgesinde yüzeyleme veren formasyonların litolojik özellikleri incelenmiş ve magmatik kökenli kayaç litolojine sahip olan Kömürhan
Ofiyolitleri'ne ait gabrolar (2), Elazı ̆ Magmatitleri'ne ait granitler (3) ve andezitler (4), Maden Karmaşığı'na ait bazaltlar (7) ile Karabakır Formasyonu'na ait bazaltların (9) balast olabilirlikleri incelenmiştir.

$\mathrm{Bu}$ kayaçlardan elde edilen agrega örnekleri üzerinde TS 7043 EN 13450 (2004) standardında önerilen laboratuvar deneyleri gerçekleştirilmiştir. Yapılan deneylere ait sonuçların değerlendirilmesi Tablo 5'te verilmiştir.

Tablo 5. Agrega örneklerinin balast olarak kullanılabilirliği

\begin{tabular}{|c|c|c|c|c|c|c|}
\hline DENEYLER & $\begin{array}{l}\text { Standartlar ve } \\
\text { Limit Değerler }\end{array}$ & 2 & 3 & 4 & 7 & 9 \\
\hline Su emme & $\begin{array}{c}\text { TS EN 1097-6 } \\
<\% 1.5\end{array}$ & 0.52 & 2.10 & 1.16 & 0.96 & 1.84 \\
\hline $\mathrm{MgSO}_{4}$ çözeltisinde don kaybı (\%) & $\begin{array}{c}\text { TS EN 1367-2 } \\
<\% 5\end{array}$ & 19.92 & 45.17 & 3.32 & 9.19 & 16.27 \\
\hline $\begin{array}{l}\text { Los Angeles parçalanma dayanımı } \\
\text { (1000 devir) }\end{array}$ & $\begin{array}{l}\text { TS EN } 1097-2 \\
<\% 20\end{array}$ & 16 & 51 & 11 & 8 & 14 \\
\hline İnce malzeme miktarı $(0.5 \mathrm{~mm}$ alt 1$)$ & $\begin{array}{l}\text { TS EN 933-1 } \\
<\% 1.0\end{array}$ & 0.77 & 1.28 & 0.19 & 0.59 & 1.40 \\
\hline $\begin{array}{l}\text { Çok ince malzeme miktarı } \\
(0.063 \mathrm{~mm} \text { altı })\end{array}$ & $\begin{array}{l}\text { TS EN 933-1 } \\
\quad<\% 0.5\end{array}$ & 0.41 & 3.78 & 0.48 & 0.31 & 1.52 \\
\hline Şekil endeksi & $\begin{array}{l}\text { TS EN 933-4 } \\
<\% 25\end{array}$ & 12 & 37 & 17 & 8 & 9 \\
\hline Yassılık endeksi & $\begin{array}{l}\text { TS EN 933-3 } \\
\quad<\% 20\end{array}$ & 19 & 7 & 5 & 5 & 1 \\
\hline Zararlı bileşenler & $\begin{array}{l}\text { TS } 1744-1 \\
<\% 0.5\end{array}$ & 0.077 & 0.284 & 0.073 & 0.061 & 0.059 \\
\hline
\end{tabular}

Tablo 5'te verilen değerlendirmeye göre, Elazığ bölgesinde yüzeyleme veren kayaçlardan sadece Elazı ̆ Magmatitleri'ne ait andezitlerin (4) tüm fiziksel, mekanik ve kimyasal özellikleri bu kayaçların demiryolu balastı olarak kullanılmasına uygundur. Diğer kayaçlardan Kömürhan Ofiyolitleri'ne ait gabrolar (2) ve Maden Karmaşı ğı'na ait bazaltların (7) $\mathrm{MgSO}_{4}$ çözeltisindeki don kaybı değerleri limit değerin çok üzerindedir. Karabakır Formasyonu'na ait bazaltların (9) su emme, $\mathrm{MgSO}_{4}$ çözeltisinde don kaybı, ince ve çok ince malzeme miktarları limit değerlerin içerisinde olmadığından bu bazaltlar da balast olarak kullanılabilme özelliğine sahip değillerdir. Elazı̆̆ Magmatitleri'ne ait granitlerin (3) tüm fiziksel ve mekanik özelliklerinin bu granitlerin balast olarak kullanılmaya uygun olmadığı belirlenmiştir.

\subsection{Kayaçların Yol Üst Yapı Malzemesi Olabilirliği}

Karayolu inşaat sektöründe agrega, beton imalatı haricinde yol üst yapısında da kullanılan en önemli doğal malzemedir. Yol çalışmalarında kullanılan agregalar, hem kaplamanın stabilitesine olan büyük katkısı hem de büyük miktarda gereksinim duyulmasından dolayı önemli bir yol malzemesidir. Çünkü, bağlayıcısız temel ve alt temel tabakalarının tamamı, bitümlü sıcak karışımların ağırlıkça \% 90-95'i ve hacimce \% 80-85'i, beton kaplamaların ağırlıkça \%70-80'i ve hacimce \%60-75'i agregalardan oluşur (Çetin, 2007).

Karayolu üstyapıları, kaplama tabakasında kullanılan malzemelerin türlerine, özelliklerine ve yapım yöntemlerine göre rijit ve esnek olmak üzere iki şekilde inşa edilirler. Rijit üstyapının kaplama tabakası çimento betonundan oluşur. Bitümlü kaplama tabakalarıyla oluşturulan üstyapılar ise esnek üstyapılardır. Karayolu esnek üstyapıları tabakalı bir üstyap1 tipidir ve bu tabakalar, en üstten alta doğru, kaplama, temel ve alt temel tabakalarından oluşurlar (Şekil 4) 


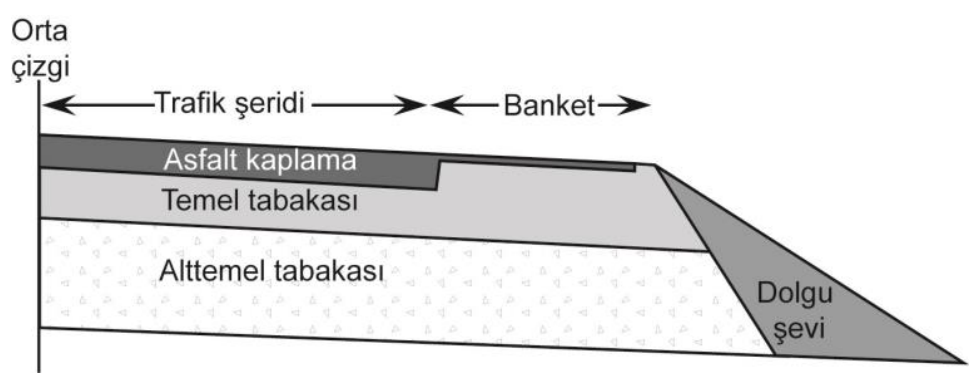

Şekil 4. Esnek üst yapı tip kesiti (Yılmaz vd., 2012)

Temel zeminin üzerine inşa edilen alt temel tabakasının görevi, yapısal olarak üstteki tabakalardan gelen yükleri dağıtarak taban zeminine iletmek ve üstteki tabakaları yeraltı suyunun zararlı etkilerinden ve don olayından korumaktır. İyi bir şekilde yapılmış olan bir alttemel tabakası, üstyapının yük taşıma kapasitesinin esasını teşkil etmesi sebebiyle üstyapıdaki oturmaları ve defleksiyonları önleyecektir. Karayolu esnek üstyapıları alt temel tabakasında, ekonomi sağlamak amaciyla yörenin yerel malzemeleri kullanılır. Çoğunlukla daha ekonomik olduğu için alt temel malzemesi olarak atık olarak tabir edilen malzemeler tercih edilmektedir. Alttemel tabakasinda kullanılan malzeme özellikleri yol mühendisliği için, özellikle taban zemini taşıma gücü düşük zeminlerde ve don tehlikesi olan zeminlerde önem arz etmekte ve uygulamalarda kullanılmaktadır. Alttemel tabakasında özellikle granüler malzemeler kullanıldığından dolayı agregaların önemi oldukça fazladır. Üstyapının ağırlıkça ve hacimce önemli bir kısmını oluşturan agrega, yola etkiyen yüklerin oluşturduğu gerilmelerin karşılanmasında önemli bir rol oynamaktadır (Findik ve Saltan, 2005).

Alttemelin üzerinde yer alan temel tabakas1 üstyapının ana yapısal elemanlarından biridir. $\mathrm{Bu}$ katmanın görevi alttemel ve tabana gelecek olan gerilmeleri kabul edilebilir seviyeye düşürerek, esneklik sağlamak ve kaplamanın hasar görmesini engellemektir. $\mathrm{Bu}$ nedenle, temel tabakasında iyi kalite malzeme kullanılır. Genel olarak granüler malzemenin kullanıldığ duruma göre çimentolu veya bitüm bağlayıcılı karışım, stabilize edilmiş malzemeler de kullanilabilmektedir.

Esnek üst yapı tipinde, en üst seviyeyi oluşturan yol kaplamaları, kaplandığı yüzeyi ve altındaki tabakaları dış etkilerden koruyarak, iyi ve estetik bir görünüm ile yol güvenliği ve yeterli konforu sağlarlar. Ayrıca, trafik ve çevre etkilerine karşı koyarak trafik yüklerini alt tabakalara iletirler. Bir asfalt kaplama yapısı, asfalt-agrega karışımından meydana gelmektedir ve kaplama içerisindeki agrega oranı hacimce \%80-85 civarındadır. Asfalt beton yol olarak tanımlanan bu yol tipinde, yollar bitümlü karışımlardan oluşan binder ve aşınma tabakalarından meydana gelmektedir. Dingil yüküne yakın olan bu seviye büyük gerilmelere maruz kaldığı için, kullanılacak malzemenin kaliteli olması gereklidir. $\mathrm{Bu}$ nedenle, üst tabakalar elastisite modülü yüksek bitümlü karışımlardan oluşmaktadır. Bitümlü sıcak karışımın (BSK) hacminin yaklaşık \%85 gibi yüksek bir miktarını oluşturan agreganın özellikleri karışım performansını etkileyen en önemli faktördür. Yol kaplamalardaki bozulmaların ana nedenlerinden birisi, karışımda kullanılan agreganın yeterli kalitede olmamasıdır. Agreganın tipi, yüzey pürüzlülüğü, yassılık durumu, gradasyonu gibi mühendislik özellikleri BSK'nın yorulma ve tekerlek izi açısından performansları üzerinde büyük bir öneme sahiptir (Tayfur vd., 2003).

Yol üstyap1 malzemesi olarak kullanılacak olan agregaların sahip olması gereken özellikler ve bu özelliklere ait limit değerler Karayolları Teknik Şartname (2013)'sinde verilmiştir. Bu çalışmada incelenen kayaçların yol üst yapı olabilirliğini belirlemek için, laboratuvar deneylerine ait sonuçlar Karayolları Teknik Şartname (2013)'sinde verilmiş olan limit değerler ile karşılaştırılmıştır (Tablo 6- 14).

İncelenen kayaçlardan Keban Metamorfitleri'ne ait kristalize kireçtaşları (1) ve Kömürhan Ofiyolitleri'ne ait gabroların (2) Los Angeles parçalanma dayanımları ile Elazı̆̆ Magmatitleri'ne ait granitlerin (3) Los Angeles parçalanma dayanımı ve $\mathrm{MgSO}_{4}$ çözeltisindeki don kaybı değerleri limit değerlerin üstündedir (Tablo 6). Dolayısıyla bu kayaçlar alttemel malzemesi olarak kullanılmaya uygun değildir. Diğer kayaçlar ise alttemel malzemesi olarak kullanılabilirler. 
Tablo 6. Agrega örneklerinin alttemel malzemesi olarak kullanılabilirliği

\begin{tabular}{|c|c|c|c|c|c|c|c|c|c|c|}
\hline DENEYLER & $\begin{array}{l}\text { Standartlar ve } \\
\text { Limit Değerler }\end{array}$ & 1 & 2 & 3 & 4 & 5 & 6 & 7 & 8 & 9 \\
\hline Su emme $(\%)$ & $\begin{array}{c}\text { TS EN 1097-6 } \\
\leq \% 3.5\end{array}$ & 0.55 & 0.52 & 2.10 & 1.16 & 0.64 & 0.95 & 0.96 & 1.09 & 1.84 \\
\hline $\mathrm{MgSO}_{4}$ çözeltisinde don kaybı (\%) & $\begin{array}{c}\text { TS EN 1367-2 } \\
\leq \% 25\end{array}$ & 9.96 & 19.92 & 45.17 & 15.32 & 7.20 & 8.24 & 9.19 & 6.80 & 16.27 \\
\hline Los Angeles parçalanma dayanımı & $\begin{array}{c}\text { TS EN 1097-2 } \\
\leq \% 45\end{array}$ & 24 & 16 & 51 & 9 & 21 & 20 & 8 & 23 & 14 \\
\hline Yassılık endeksi & $\begin{array}{c}\text { TS EN 933-3 } \\
\leq \% 30\end{array}$ & 2 & 19 & 7 & 5 & 11 & 7 & 5 & 2 & 1 \\
\hline
\end{tabular}

Not: Gri alanlardaki değerler standartlara uygun olan değerleri göstermektedir.

Tablo 7'ye göre kayaçların temel malzemesi olarak kullanılmaya uygun olmayan tek birim Elazığ Magmatitleri'ne ait granitlerdir (3). Diğer kayaçlara ait değerler (Tablo 7), Karayolları
Teknik Şartname (2013)'sinde verilmiş olan limit değerlere uygundur ve temel malzemesi olarak kullanılabilirler.

Tablo 7. Agrega örneklerinin temel malzemesi olarak kullanılabilirliği

\begin{tabular}{|c|c|c|c|c|c|c|c|c|c|c|}
\hline DENEYLER & $\begin{array}{l}\text { Standartlar ve } \\
\text { Limit Değerler }\end{array}$ & 1 & 2 & 3 & 4 & 5 & 6 & 7 & 8 & 9 \\
\hline Su emme $(\%)$ & $\begin{array}{c}\text { TS EN 1097-6 } \\
\leq \% 3.0\end{array}$ & 0.55 & 0.52 & 2.10 & 1.16 & 0.64 & 0.95 & 0.96 & 1.09 & 1.84 \\
\hline $\mathrm{MgSO}_{4}$ çözeltisinde don kaybı (\%) & $\begin{array}{c}\text { TS EN 1367-2 } \\
\leq \% 20\end{array}$ & 9.96 & 19.92 & 45.17 & 15.32 & 7.20 & 8.24 & 9.19 & 6.80 & 16.27 \\
\hline Los Angeles parçalanma dayanımı & $\begin{array}{c}\text { TS EN 1097-2 } \\
\leq \% 35\end{array}$ & 24 & 16 & 51 & 9 & 21 & 20 & 8 & 23 & 14 \\
\hline Yassilık endeksi & $\begin{array}{c}\text { TS EN 933-3 } \\
\leq \% 25\end{array}$ & 2 & 19 & 7 & 5 & 11 & 7 & 5 & 2 & 1 \\
\hline
\end{tabular}

Not: Gri alanlardaki değerler standartlara uygun olan değerleri göstermektedir.

Kayaçlar bitümlü sathi kaplama malzemesi olarak kullanılabilirliği açısından değerlendirildiğinde (Tablo 8), Keban Metamorfitleri'ne ait kristalize kireçtaşlarının (1) Mikro Deval aşınma direncinin ve Kömürhan Ofiyolitleri'ne ait gabroların (2) ve
Elazı̆̆ Magmatitleri'ne ait granitlerin (3) $\mathrm{MgSO}_{4}$ çözeltisindeki don kaybı değerlerinin limit değerlerin üstünde olduğu belirlenmiştir. Bu nedenle, bu kayaçların bitümlü sathi kaplama malzemesi olarak kullanılması sakıncalıdır.

Tablo 8. Agrega örneklerinin bitümlü sathi kaplama malzemesi olarak kullanılabilirliği

\begin{tabular}{|c|c|c|c|c|c|c|c|c|c|c|}
\hline DENEYLER & $\begin{array}{l}\text { Standartlar ve } \\
\text { Limit Değerler }\end{array}$ & 1 & 2 & 3 & 4 & 5 & 6 & 7 & 8 & 9 \\
\hline Su emme $(\%)$ & $\begin{array}{l}\text { TS EN 1097-6 } \\
\leq \% 2.5\end{array}$ & 0.55 & 0.52 & 2.10 & 1.16 & 0.64 & 0.95 & 0.96 & 1.09 & 1.84 \\
\hline $\mathrm{MgSO}_{4}$ çözeltisinde don kaybı (\%) & $\begin{array}{c}\mathrm{TS} \text { EN 1367-2 } \\
\leq \% 18\end{array}$ & 9.96 & 19.92 & 45.17 & 15.32 & 7.20 & 8.24 & 9.19 & 6.80 & 16.27 \\
\hline Los Angeles parçalanma dayanımı & $\begin{array}{c}\mathrm{TS} \text { EN 1097-2 } \\
\leq \% 35\end{array}$ & 24 & 16 & 51 & 9 & 21 & 20 & 8 & 23 & 14 \\
\hline Mikro Deval aşınma direnci & $\begin{array}{c}\text { TS EN 1097-1 } \\
\leq \% 25\end{array}$ & 27 & 15 & 20 & 15 & 17 & 10 & 11 & 18 & 13 \\
\hline Yassilık endeksi & $\begin{array}{c}\text { TS EN 933-3 } \\
\leq \% 20\end{array}$ & 2 & 19 & 7 & 5 & 11 & 7 & 5 & 2 & 1 \\
\hline
\end{tabular}

Not: Gri alanlar standartlara uygun olan değerleri göstermektedir.

Bu çalışmada incelenen kayaçların makadam sathi kaplama, bitümlü koruyucu sathi kaplama, bitümlü temel ve binder malzemesi olarak kullanılabilirliği açısından değerlendirildiğinde; Keban Metamorfitleri'ne ait kristalize kireçtaşlarının (1) Mikro Deval aşınma direnci, Kömürhan Ofiyolitleri'ne ait gabroların (2) $\mathrm{MgSO}_{4}$ çözeltisindeki don kaybı ve Elazığ
Magmatitleri'ne ait granitlerin (3) $\mathrm{MgSO}_{4}$ çözeltisindeki don kaybı ile Los Angeles parçalanma direnci değerlerinin standartlarda verilen limit değerlere uygun olmadı̆̆ belirlenmiştir (Tablo 9, 10 ve 11). Bu nedenle, bu kayaçların makadam sathi kaplama, bitümlü koruyucu sathi kaplama, bitümlü temel ve binder malzemesi olarak kullanılmamalıdır. 
Tablo 9. Agrega örneklerinin makadam sathi kaplama malzemesi olarak kullanılabilirliği

\begin{tabular}{|c|c|c|c|c|c|c|c|c|c|c|}
\hline DENEYLER & $\begin{array}{l}\text { Standartlar ve } \\
\text { Limit Değerler }\end{array}$ & 1 & 2 & 3 & 4 & 5 & 6 & 7 & 8 & 9 \\
\hline Su emme $(\%)$ & $\begin{array}{c}\text { TS EN 1097-6 } \\
\leq \% 3.0\end{array}$ & 0.55 & 0.52 & 2.10 & 1.16 & 0.64 & 0.95 & 0.96 & 1.09 & 1.84 \\
\hline $\mathrm{MgSO}_{4}$ çözeltisinde don kaybı (\%) & $\begin{array}{c}\text { TS EN 1367-2 } \\
\leq \% 18\end{array}$ & 9.96 & 19.92 & 45.17 & 15.32 & 7.20 & 8.24 & 9.19 & 6.80 & 16.27 \\
\hline Los Angeles parçalanma dayanımı & $\begin{array}{c}\text { TS EN 1097-2 } \\
\leq \% 30\end{array}$ & 24 & 16 & 51 & 9 & 21 & 20 & 8 & 23 & 14 \\
\hline Mikro Deval aşınma direnci & $\begin{array}{l}\text { TS EN 1097-1 } \\
\leq \% 25\end{array}$ & 27 & 15 & 20 & 15 & 17 & 10 & 11 & 18 & 13 \\
\hline Yassılık endeksi & $\begin{array}{c}\text { TS EN 933-3 } \\
\leq \% 20\end{array}$ & 2 & 19 & 7 & 5 & 11 & 7 & 5 & 2 & 1 \\
\hline
\end{tabular}

Not: Gri alanlar standartlara uygun olan değerleri göstermektedir.

Tablo 10. Agrega örneklerinin bitümlü koruyucu sathi kaplama ve bitümlü temel malzemesi olarak kullanılabilirliği

\begin{tabular}{|c|c|c|c|c|c|c|c|c|c|c|}
\hline DENEYLER & $\begin{array}{l}\text { Standartlar ve } \\
\text { Limit Değerler }\end{array}$ & 1 & 2 & 3 & 4 & 5 & 6 & 7 & 8 & 9 \\
\hline Su emme $(\%)$ & $\begin{array}{l}\text { TS EN 1097-6 } \\
\leq \% 2.5\end{array}$ & 0.55 & 0.52 & 2.10 & 1.16 & 0.64 & 0.95 & 0.96 & 1.09 & 1.84 \\
\hline $\mathrm{MgSO}_{4}$ çözeltisinde don kaybı (\%) & $\begin{array}{c}\text { TS EN 1367-2 } \\
\leq \% 18\end{array}$ & 9.96 & 19.92 & 45.17 & 15.32 & 7.20 & 8.24 & 9.19 & 6.80 & 16.27 \\
\hline Los Angeles parçalanma dayanımı & $\begin{array}{c}\mathrm{TS} \text { EN 1097-2 } \\
\leq \% 30\end{array}$ & 24 & 16 & 51 & 9 & 21 & 20 & 8 & 23 & 14 \\
\hline Mikro Deval aşınma direnci & $\begin{array}{l}\text { TS EN 1097-1 } \\
\leq \% 25\end{array}$ & 27 & 15 & 20 & 15 & 17 & 10 & 11 & 18 & 13 \\
\hline Yassılık endeksi & $\begin{array}{c}\text { TS EN 933-3 } \\
\leq \% 20\end{array}$ & 2 & 19 & 7 & 5 & 11 & 7 & 5 & 2 & 1 \\
\hline
\end{tabular}

Not: Gri alanlar standartlara uygun olan değerleri göstermektedir.

Tablo 11. Agrega örneklerinin asfalt betonu (binder) malzemesi olarak kullanılabilirliği

\begin{tabular}{|c|c|c|c|c|c|c|c|c|c|c|}
\hline DENEYLER & $\begin{array}{l}\text { Standartlar ve } \\
\text { Limit Değerler }\end{array}$ & 1 & 2 & 3 & 4 & 5 & 6 & 7 & 8 & 9 \\
\hline Su emme $(\%)$ & $\begin{array}{l}\text { TS EN 1097-6 } \\
\leq \% 2.5\end{array}$ & 0.55 & 0.52 & 2.10 & 1.16 & 0.64 & 0.95 & 0.96 & 1.09 & 1.84 \\
\hline $\mathrm{MgSO}_{4}$ çözeltisinde don kaybı (\%) & $\begin{array}{c}\text { TS EN 1367-2 } \\
\leq \% 18\end{array}$ & 9.96 & 19.92 & 45.17 & 15.32 & 7.20 & 8.24 & 9.19 & 6.80 & 16.27 \\
\hline Los Angeles parçalanma dayanımı & $\begin{array}{c}\text { TS EN 1097-2 } \\
\leq \% 30\end{array}$ & 24 & 16 & 51 & 9 & 21 & 20 & 8 & 23 & 14 \\
\hline Mikro Deval aşınma direnci & $\begin{array}{l}\text { TS EN 1097-1 } \\
\leq \% 25\end{array}$ & 27 & 15 & 20 & 15 & 17 & 10 & 11 & 18 & 13 \\
\hline Yassilık endeksi & $\begin{array}{c}\text { TS EN 933-3 } \\
\leq \% 25\end{array}$ & 2 & 19 & 7 & 5 & 11 & 7 & 5 & 2 & 1 \\
\hline
\end{tabular}

Not: Gri alanlar standartlara uygun olan değerleri göstermektedir.

Kayaçların binder malzemesi olarak kullanılabilirliğinin değerlendirilmesi Tablo 12' de verilmiştir. $\mathrm{Bu}$ değerlendirmeye göre; Keban Metamorfitleri'ne ait kristalize kireçtaşlarının (1) Mikro Deval aşınma direnci, Kömürhan Ofiyolitleri'ne ait gabrolar (2) ile Karabakır Formasyonu'na ait bazaltlarm (9) $\mathrm{MgSO}_{4}$ çözeltisindeki don kaybı ve Elazı ̆ Magmatitleri'ne ait granitlerin (3) $\mathrm{MgSO}_{4}$ çözeltisindeki don kaybı ve Los Angeles parçalanma direnci değerlerinin şartnamede belirtilen limit değerlere uygun olmadığı ve bu kayaçların beton asfaltta aşınma malzemesi olarak kullanılmaya uygun olmadığı belirlenmiştir.
İncelenen kayaçlardan Keban Metamorfitleri'ne ait kristalize kireçtaşlarının (1) Mikro Deval aşınma direnci, Kömürhan Ofiyolitleri'ne ait gabrolar (2), Elazı ̆̆ Magmatitlerine ait andezitler (4) ve Karabakır Formasyonu'na ait bazaltların (9) $\mathrm{MgSO}_{4}$ çözeltisindeki don kaybı değerleri, Elazı ̆ Magmatitleri'ne ait granitlerin (3) ise su emme, $\mathrm{MgSO}_{4}$ çözeltisindeki don kaybı ve Los Angeles parçalanma direnci değerleri Karayolları Teknik Şartname (2013)'sinde verilmiş olan limit değerlere uygun değildir (Tablo 13). Bu nedenle, taş mastik malzemesi olarak kullanılamazlar. 
Tablo 12. Agrega örneklerinin asfalt betonu (aşınma) malzemesi olarak kullanılabilirliği

\begin{tabular}{|c|c|c|c|c|c|c|c|c|c|c|}
\hline DENEYLER & $\begin{array}{l}\text { Standartlar ve } \\
\text { Limit Değerler }\end{array}$ & 1 & 2 & 3 & 4 & 5 & 6 & 7 & 8 & 9 \\
\hline Su emme $(\%)$ & $\begin{array}{l}\text { TS EN 1097-6 } \\
\leq \% 2.0\end{array}$ & 0.55 & 0.52 & 2.10 & 1.16 & 0.64 & 0.95 & 0.96 & 1.09 & 1.84 \\
\hline $\mathrm{MgSO}_{4}$ çözeltisinde don kaybı (\%) & $\begin{array}{c}\text { TS EN 1367-2 } \\
\leq \% 16\end{array}$ & 9.96 & 19.92 & 45.17 & 15.32 & 7.20 & 8.24 & 9.19 & 6.80 & 16.27 \\
\hline Los Angeles parçalanma dayanımı & $\begin{array}{c}\text { TS EN 1097-2 } \\
\leq \% 27\end{array}$ & 24 & 16 & 51 & 9 & 21 & 20 & 8 & 23 & 14 \\
\hline Mikro Deval aşınma direnci & $\begin{array}{l}\text { TS EN 1097-1 } \\
\leq \% 20\end{array}$ & 27 & 15 & 20 & 15 & 17 & 10 & 11 & 18 & 13 \\
\hline Yassıllik endeksi & $\begin{array}{c}\text { TS EN 933-3 } \\
\leq \% 20\end{array}$ & 2 & 19 & 7 & 5 & 11 & 7 & 5 & 2 & 1 \\
\hline
\end{tabular}

Not: Gri alanlar standartlara uygun olan değerleri göstermektedir.

Tablo 13. Agrega örneklerinin taş mastik malzemesi olarak kullanılabilirliği

\begin{tabular}{|c|c|c|c|c|c|c|c|c|c|c|}
\hline DENEYLER & $\begin{array}{l}\text { Standartlar ve } \\
\text { Limit Değerler }\end{array}$ & 1 & 2 & 3 & 4 & 5 & 6 & 7 & 8 & 9 \\
\hline Su emme $(\%)$ & $\begin{array}{l}\text { TS EN 1097-6 } \\
\leq \% 2.0\end{array}$ & 0.55 & 0.52 & 2.10 & 1.16 & 0.64 & 0.95 & 0.96 & 1.09 & 1.84 \\
\hline $\mathrm{MgSO}_{4}$ çözeltisinde don kaybı (\%) & $\begin{array}{c}\text { TS EN 1367-2 } \\
\leq \% 14\end{array}$ & 9.96 & 19.92 & 45.17 & 15.32 & 7.20 & 8.24 & 9.19 & 6.80 & 16.27 \\
\hline Los Angeles parçalanma dayanımı & $\begin{array}{c}\mathrm{TS} \text { EN 1097-2 } \\
\leq \% 25\end{array}$ & 24 & 16 & 51 & 9 & 21 & 20 & 8 & 23 & 14 \\
\hline Mikro Deval aşınma direnci & $\begin{array}{c}\text { TS EN 1097-1 } \\
\leq \% 20\end{array}$ & 27 & 15 & 20 & 15 & 17 & 10 & 11 & 18 & 13 \\
\hline Yassilık endeksi & $\begin{array}{c}\text { TS EN 933-3 } \\
\leq \% 20\end{array}$ & 2 & 19 & 7 & 5 & 11 & 7 & 5 & 2 & 1 \\
\hline
\end{tabular}

Not: Gri alanlar standartlara uygun olan değerleri göstermektedir.

Kayaçlara ait laboratuvar sonuçlarının değerlendirilmesi sonucunda (Tablo 14), Kömürhan Ofiyolitleri'ne ait gabrolar (2) ile
Elazığ Magmatitleri'ne ait granitlerin (3) bitümlü karışım bakım malzemesi olarak kullanılmaya uygun olmadıkları belirlenmiştir.

Tablo 14. Agrega örneklerinin bitümlü karışım bakım malzemesi olarak kullanılabilirliği

\begin{tabular}{|c|c|c|c|c|c|c|c|c|c|c|}
\hline DENEYLER & $\begin{array}{l}\text { Standartlar ve } \\
\text { Limit Değerler }\end{array}$ & 1 & 2 & 3 & 4 & 5 & 6 & 7 & 8 & 9 \\
\hline Su emme $(\%)$ & $\begin{array}{l}\text { TS EN 1097-6 } \\
\leq \% 2.5\end{array}$ & 0.55 & 0.52 & 2.10 & 1.16 & 0.64 & 0.95 & 0.96 & 1.09 & 1.84 \\
\hline $\mathrm{MgSO}_{4}$ çözeltisinde don kaybı (\%) & $\begin{array}{c}\text { TS EN 1367-2 } \\
\leq \% 18\end{array}$ & 9.96 & 19.92 & 45.17 & 15.32 & 7.20 & 8.24 & 9.19 & 6.80 & 16.27 \\
\hline Los Angeles parçalanma dayanımı & $\begin{array}{c}\text { TS EN 1097-2 } \\
\leq \% 30\end{array}$ & 24 & 16 & 51 & 9 & 21 & 20 & 8 & 23 & 14 \\
\hline Yass1lık endeksi & $\begin{array}{c}\text { TS EN 933-3 } \\
\leq \% 25\end{array}$ & 2 & 19 & 7 & 5 & 11 & 7 & 5 & 2 & 1 \\
\hline
\end{tabular}

Not: Gri alanlar standartlara uygun olan değerleri göstermektedir.

\section{Sonuçlar ve Öneriler}

Elazığ bölgesinde yüzeyleme veren ve kırmataş olarak kullanılma potansiyeline sahip olduğu düşünülen formasyonlardan derlenen örneklerde gerçekleştirilen laboratuvar deneylerine ait sonuçlar, beton agregası, balast, yol üst yap1 malzemesi gibi kullanım alanına göre standartlarda verilen limit değer ile karşılaştırılmış ve bu kayaçların beton agregası, balast ve yol üst yap1 malzemesi olabilirlikleri belirlenmiştir.
Yapılan çalışmalardan elde edilen sonuçları kısaca şu şekilde sıralamak mümkündür;

1. Kayaçların beton agregası olarak kullanılabilirliği konusunda yapılan değerlendirmeler Elazı̆̆ Magmatitleri'ne ait andezitler (4), Harami Formasyonu'na ait kireçtaşları (5), Maden Karmaşı̆̆ı'na ait bazaltlar (7) ve Kırkgeçit Formasyonu'na ait kireçtaşlarının (8) beton agregası olarak değerlendirilebileceğini göstermektedir. Bölgede yüzeyleme veren diğer kayaçlara ait sonuçlara göre, bu kayaçların beton 
agregası olarak kullanılması sakıncalıdır veya kullanırken dikkatli olunmalıdır. Nitekim, halen beton agregası olarak kullanılan Keban Metamorfitleri'ne ait kristalize kireçtaşlarının (1) mikro deval aşınma direnci düşük olduğundan, bu kayaçlara ait agregalar ile üretilen betonun aşınmaya maruz kalacak alanlarda kullanılmasından kaçınılması gerekmektedir. Ayrıca, Seske Formayonu'na ait kireçtaşlarının (6) asitte çözünebilen sülfat değeri ile Karabakır Formasyonu'na ait bazaltların (9) metilen mavisi değerleri (MB) limit değerlerden fazla olmasına karşın, bu kayaçlarda beton agregası olarak kullanılmaktadır. Kireçtaşı agregasının (6) sülfat oranı değişiklik gösterebileceğinden, sülfat değerinin rutin olarak kontrol edilmesi ve aşırı yükselim durumunda bu kireçtaşlarının beton agregası olarak kullanılmaması gerekmektedir. Karabakır Formasyonu'na ait bazaltlarda (9) ise metilen mavisi değeri (MB) limit değerlerin üstündedir. Bu durum agregada çok ince malzeme miktarının fazla olduğunu ve agreganın kirli olduğunu göstermektedir. $\mathrm{Bu}$ kirliliğin, bazaltlardaki gaz boşluklarında var olan ikincil minerallerden kaynaklanmaktadır. $\mathrm{Bu}$ nedenle beton agregası olarak kullanılacak bazaltların gaz boşluksuz olmasına dikkat edilmelidir.

2. İncelenen kayaçlardan demiryolu balastı olabilecek litolojiye sahip olan Kömürhan Ofiyolitleri'ne ait gabrolar (2), Elazı̆ Magmatitleri'ne ait granitler (3) ve andezitler (4), Maden Karmaşı̆̆ı'na ait bazaltlar (7) ile Karabakır Formasyonu'na ait bazaltlara (9) ait sonuçlar, bu kayaçlardan sadece Elazı̆ Magmatitleri'ne ait andezitlerin (4) demiryolu balastı olarak kullanılabileceğini göstermektedir. Diğer kayaçların ise özelikle $\mathrm{MgSO}_{4}$ çözeltisindeki don kayıpları oldukça yüksektir. $\mathrm{Bu}$ kayaçların balast olarak kullanılması durumunda, balast kirlenmesi gerçekleşecek ve balast fiziksel özelliklerini kaybederek işlev göremez hale gelecektir. Bölgenin balast olarak kullanılabilecek tek birimi olan bu andezitik kayaçların yayılım ve özelliklerini daha detaylı olarak belirlenmesi, önümüzdeki süreçte devam edecek olan hızlı tren projelerinin balast ihtiyacının karşılanabilmesi açısından önem taşımaktadır.

3. Bölgedeki kayaçların yol üst yapı malzemesi olarak kullanılabilirliği açısından yapılan değerlendirmelerde, bölgedeki kayaçlardan Harami Formasyonu'na ait kireçtaşları (5), Seske Formasyonu'na ait kireçtaşları (6), Maden Karmaşığı'na ait bazaltlar (7) ve Kırkgeçit Formasyonu'na ait kireçtaşlarının (8) yol üst yapısındaki tüm katmanlarında kullanılabilecek özellikte olduğunu göstermektedir. Elazı ̆ Magmatitleri'ne ait granitler (3) ise yol üst yap1 malzemesi olarak kullanılabilir değildir. Diğer kayaçlardan Keban Metamorfitleri'ne ait kristalize kireçtaşları (1) sadece temel ve bitümlü karışım bakım malzemesi olarak kullanılmaya uygun iken, Kömürhan Ofiyoltileri'ne ait gabrolar (2) ise sadece temel malzemesi olarak kullanılabilmeye uygundur. Elazığ Magmatitleri'ne ait andezitlerin (4) taş mastik malzemesi haricinde, yol üst yapısının bütün alanlarında kullanılabilir özellikte olduğu, Karabakır Formasyonu'na ait bazaltların (9) ise aşınma ve taş mastik malzemesi hariç diğer alanlarda kullanılmaya uygun özelliklerde olduğu belirlenmiştir. $\mathrm{Bu}$ çalışmada, yol üst yapı malzemesi için yapılan değerlendirmelerde, sadece iri agrega özelliklerinin dikkate alınmıştır. $\mathrm{Bu}$ nedenle, bu kayaçların kesin olarak kullanılabilir olduğuna karar verebilmek için Karayollar1 Teknik Şartname (2013)'sinde önerilen ince agrega ve bitümlü karışımlarda yapılması gereken diğer deneylerin de yapılması gereklidir.

4. $\mathrm{Bu}$ çalı̧̧ma sonucunda elde edilen değerlerin, örnek alınan lokasyanları temsil ettiği, litolojik özellikler aynı olsa bile farklı lokasyonlardan yapılacak olan örneklerden ortaya çıkacak sonuçların farklı olabileceği, bu nedenle kırmataş olarak işletilmesi planlanan alanlar için örnekleme yapılarak deneylerin gerçekleştirilmesi gerektiği unutulmamalıdır.

\section{Kaynaklar}

Adam, D., Brandl, H. ve Paulmichl, I., 2010. Dynamic Aspects of Rail Tracks for High-Speed Railways. International Journal of Pavement Engineering, 11, 281-291.

Akbulut, H., Çetin, S. ve Gürer, C., 2009. Andezit Agregasının Sicak Karışım Asfalt Kaplamalarında Kullanılabilirliğinin Araştırılması, 5.Uluslararası İleri Teknolojiler Sempozyumu Bildirileri, 13-15 Mayıs 2009, Karabük, s. 167.

Akpınar Ş., Gonak G. ve Pamukçu, Ç. 2004. Değişik Kökenli Agregaların Beton Kalitesi Üzerindeki Etkilerinin İncelenmesi 5. Endüstriyel Hammaddeler Sempozyumu Bildirileri. 13-14 Mayıs 2004, İzmir, s. 374-382.

Aksoy, E., Türkmen, İ., ve Turan, M., 2005. Tectonics And Sedimentation in Convergent Margin Basins: An Example From The Tertiary Elazı ğ Basin, Eastern Turkey. Journal of Asian Earth Sciences, 25, 459-472. 
Aksoy, E., 1993. Elazı ̆ Batı ve Güneyinin Genel Jeolojik Özellikleri. Doğa Türk Yerbilimleri Dergisi, 1(1), 113-123.

Aktaş, G. ve Robertson, A.H.F., 1990. Late Cretaceous-Early Tertiary Fore-Arc Tectonics And Sedimentation: Maden Complex, 1-6 October 1990, SE Turkey, in Proceedings of the International Earth Sciences Congress on Aegean Regions, (Eds. Savaşçin, M.Y., and Eronat, A.H.), İzmir, pp. 271-276.

Alexander, M.G. ve Milne, T.I., 1995. Influence of Cement Blent and Aggregate Type on Stress Strain Behavior and Elastic Modulus of Concrete. ACI Materials Journal, 92(MayJune), 227-235,

Altunbey, M. ve Çelik, S., 2005. Anayatak (MadenElazığ) Bakır Cevherleşmesinin Jeolojik, Mineralojik ve Jeokimyasal Özellikleri. Geosound/Yerbilimleri, 47, 63-90.

Apaydın, Ö.F. ve Yılmaz, M., 2019. Bazaltik Kayaçların Balast Kirlenmesi Yönünden Karşılaştırılması. Ömer Halisdemir Üniversitesi Mühendislik Bilimleri Dergisi, 8(1), 296-311.

Arıoğlu, E., Kurt, G., Yoldaş, R. ve Yalçın, H., 2009. Kimi kayaçların Çok Yüksek Devirli (>500) Los Angeles Aşınma Değerleri, 5. Ulusal Kırmataş Sempozyumu Bildirileri, 1-2 Aralık 2009, İstanbul, s. 93-101

Baska M.A., 2006. Betonun Basınç Dayanımının Belirlenmesi ve Değerlendirilmesi, Yüksek Lisans Tezi, Atatürk Üniversitesi Fen Bilimleri Enstitüsü, Erzurum, 50s.

Canadian Standards Association (CSA), 2014., CANADA CSA A23.2-25A-14 / Test Method for Detection of Alkali-Silica Reactive Aggregate by Accelerated Expansion of Mortar Bars. CSA A23.2-00: Methods of Test for Concrete, Canadian Standards Association, Mississauga $(\mathrm{ON})$.

Cilason., N., 1992. Beton: İstanbul, STFA Yayınları, No: 21, $256 \mathrm{~s}$.

Coşkun, E. ve Zorlu, K., 2018. Ultramafik Kayaçların Agrega Üretiminde Kaynak Kayaç Olarak Kullanılabilirliğinin Araştırılması, 71. Türkiye Jeoloji Kurultayı Bildirileri, 23-27 Nisan 2018, Ankara, s. 649-650.

Çetin, S., 2007. Afyon Karahisar Bölgesi Volkanik Kayaçlarının Sıcak Karışım Asfalt Kaplamalarında Agrega Olarak Kullanılabilirliğinin Araştırılması. Yüksek Lisans Tezi, Kocatepe Üniversitesi Fen Bilimleri Enstitüsü, Afyon, 90s.
Çokmak, B., 2007. Isparta Yöresinde Çıkarılan ve Beton Üretiminde Agrega Olarak Kullanılan Malzemelerin Özelliklerinin Belirlenmesi. Yüksek Lisans Tezi, Süleyman Demirel Üniversitesi Fen Bilimleri Enstitüsü, Isparta, $47 \mathrm{~s}$.

Davraz, M., Gündüz, L., Şapçı, N. ve Başpınar, E. 2007. Isparta Civarı Volkanik Kayaçların Mühendislik Özellikleri ve Taşıyıcı Beton Üretiminde Kullanılabilirliği, 6. Uluslararası Endüstriyel Hammaddeler Sempozyumu Bildirileri, 1-3 Şubat 2007, İzmir, s. 172-184.

Di Giuseppe, P., Agostini, S., Lustrino, M., Karaoğlu, Ö., Savaşçın, M.Y., Manetti, P. ve Ersoy, Y., 2018. Transition from Compression to StrikeSlip Tectonics Revealed by Miocene Pleistocene Volcanism West of the Karliova Triple Junction (East Anatolia). Journal of Petrology, 58(10), 2055-2087.

Doğan, K. S., 2006. Zonguldak-Sapça Taş Ocağ Agregalarının Fiziksel ve Mekanik Özellikleri. Yüksek Lisans Tezi, Z.K.Ü. Fen Bilimleri Enstitüsü, Zonguldak, 56s.

Dunham, R.J., 1962. Classification of Carbonate Rocks According to Depositional Texturei, in: W.E. Ham. (Ed.), Classification of Carbonate Rocks, Tulsa, Oklahoma, pp.108-121.

Erdoğan, B., 1982. Ergani-Maden Yöresindeki Güneydoğu Anadolu Ofiyolit Kuşağının Jeolojisi ve Volkanik Kayaçları. Türkiye Jeoloji Kurumu Bülteni, 25, 49-50.

Erdoğan, Y.T., 1995. Betonu Oluşturan Malzemeler; AGREGA: İstanbul, Türkiye Hazır Beton Birliği Yayını, 110s.

Fındık F.S. ve Saltan M., 2005. Hafif Agregaların Esnek Üstyap1 Alttemelinde Kullanılabilirliğinin Araştırılması, Antalya Yöresinin İnşaat Mühendisliği Sorunları Kongresi Bildirileri, 22-24 Eylül 2005, Antalya, s. 384 .

Giaccio, G., Rocco, C., Violini, D., Zappitelli, J. ve Zerbino, R., 1992. High-Strength Concretes Incorporating Different Coarse Aggregates. ACI Materials Journal, 3, 242-246.

Güçlüer, K., Günaydin, O., Tekin, Ö.F. ve Şahan, M.F., 2017.Farklı Tipte Agrega Kulanımının Betonun Mekanik Özeliklerine Etkisinin Araştırılması. Ömer Halisdemir Üniversitesi Mühendislik Bilimleri Dergisi, 6(1), 107-114.

Gürbüz, G., 1998. Amasya Bölgesi Agrega Rezervlerinin Hazır Beton Agregası Olarak Kullanım İmkanlarının Araştırılması. Yüksek Lisans Tezi, Gazi Üniversitesi Fen Bilimleri Enstitüsü, Ankara, 77s. 
Gürocak, Z., 2016. Dedeyolu Köyü (Sivrice-Elazığ) Civarındaki Geç Kretase Yaşlı Bazaltların Kırmataş Olarak Kullanılabilirliğinin Araştırılması. Pamukkale Üniversitesi Mühendislik Bilimleri Dergisi, 22(6), 527-534.

Hartle A., 1974. A Review of the Geological Factors Influencing the Mechanical Properties on Road Surface Aggregates. Engineering Geology, 7(1), 69-100.

Huang, H., 2010. Discrete Element Modeling of Railroad Ballast Using Imaging Based Aggregate Morphology Characterization. PhD Thesis, Department of Civil and Environmental Engineering University of Illinois at Urbana Champaign, 164p.

İbilioğlu, D., 2008. Elazığ Havzası Paleojen İstifinin Mikropaleontolojik (Planktonik Foraminifer ve Ostrakodlarının) İncelenmesi ve Ortamsal Yorumu. Doktora Tezi, Çukurova Üniversitesi Fen Bilimleri Enstitüsü, Adana, 189s.

Karacan, D.S., 2006. Zonguldak-Sapça Taş Ocağ1 Agregalarının Fiziksel ve Mekanik Özellikleri. Yüksek Lisans Tezi, Karaelmas Üniversitesi Fen Bilimleri Enstitüsü, Zonguldak, 112s.

Karayolları Teknik Şartnamesi, 2013. Yol Alt Yapıs1, Sanat Yapıları, Köprü ve Tüneller, Üst Yapı ve Çeşitli İşler. Karayolları Genel Müdürlüğü, Ankara.

Kaya, A., 2014. Keban Metamorfitleri'nin Stratigrafisine İlişkin Yeni Yaş Bulguları. Pamukkale Üniversitesi, Mühendislik Bilimleri Dergisi, 22(3), 189-199.

Kazi, A. ve Al-Mansour, Z.R., 1980. Influence of Geological Factors on Abrasion and Soundness Characteristics of Aggregates. Engineering Geology, 15(3-4), 195-203.

Ketin, İ., 1966. Anadolu'nun Tektonik Birlikleri. MTA Dergisi, 66, 20-34.

Kılıç, A. ve Keskin, M., 2003. Doğu Karadeniz Yöresi Taş Ocakları Malzemelerinin Kırmataş Olarak Değerlendirme Olanakları. III. Ulusal Kırmataş Sempozyumu Bildirileri, 3-4 Aralık 2003, İstanbul, s.301-306.

Kırca, S., 2001. Sütçüler-Menteşe Çakıl Agregasının Beton İmalinde Kullanılmasının Araştırılması, Yüksek Lisans Tezi, Süleyman Demirel Üniversitesi, Fen Bilimleri Enstitüsü, Isparta, 88 s.

Kocal, F., 1999, Trabzon-Maçka Başar Taşocağındaki Kireçtaşının Agrega Olma Açısından İncelenmesi. Türkiye 16. Madencilik Kongresi Bildirileri, 15-18 Haziran 1999, Ankara, s. 279285.
Konak, G., Onur, H.A., Karakuş, D. 2009. İnşaat Sektörünün İhtiyacı Olan Agreganın İşletilmesi ve Kentsel Faydaları. TMMOB İzmir Kent Sempozyumu Bildirileri, 10 Ocak 2009, İzmir, s. 229-236.

Koralay, T., Çobanoğlu, İ. ve Demir, M., 2014. Ofiyolitler İçerisindeki Gabro Dayklarının Balast Malzemesi Olarak Kullanılabilirliği: İnceler (Bozkurt-Denizli) Örneği. KSU Mühendislik Bilimleri Dergisi, 17(2), 32-48.

Korkanç, M. ve Tuğrul, A., 2004. Evaluation of Selected Basalts from Niğde, Turkey, as Source of Concrete Aggregate. Engineering Geology, 75(3-4), 291-307.

Kürüm, S. ve Tanyıldızı, Ö., 2017. Geochemical and $\mathrm{Sr}-\mathrm{Nd}$ Isotopic Characteristics of Upper Cretaceous (Calc-alkaline) and Miocene (Alkaline) Volcanic Rocks: Elazıg, Eastern Taurides, Turkey. Journal of African Earth Sciences, 134, 332-344.

Lees, G. ve Kennedy, C.K., 1975. Quality, Shape and Degradation of Aggregates. Quarterly Journal of Engineering Geology, 8, 28-35.

Oğul, K., Topal, İ. ve Poşluk, E., 2012. Ankara İstanbul Yüksek Hızlı Tren Demiryolunda Balast Hammaddesi Olarak Granit ve Bazaltın Birlikte Kullanılabilirliğinin Araştırılması ve Aşınma Dayanımlarına Etkisi. Yeraltı Kaynakları Dergisi, 1(1), 81-89.

Öz, E., 2007. Nevşehir Dolaylarında Yüzeylenen Asidik Pomzanın Hafif Beton Agregası Olarak Kullanılabilirliği. Yüksek Lisans Tezi, Ç.Ü. Fen Bilimleri Enstitüs, Adana, 52s.

Özgen-Erdem, N., İnan, N. ve Akyaz1, M., 1993. Harabeykayış, Formasyonu'nun (Elazı̆̆g) tanımlaması. Türkiye Jeoloji Kurultayı Bülteni 8, 135-147.

Özturan, T. ve Çeçen, C., 1997. Effect of Coarse Aggregate Type Onmechanical Properties of Concretes With Different Strengths. Cement and Concrete Research, 27(2), 165-170.

Perinçek, D., 1979a. The Geology of Hazro-KorudağCungus-Maden-Ergani-Hazar-Elazığ-Malatya Area: Guide Book, Türkiye. Jeoloji Kurumu. Bülteni, 33s.

Perinçek, D., 1979b. Interrelations of the Arabian and Anatolian Plates. Guide Book for Excursion 'B' First Geological Congress on Middle East, the Geological Society of Turkey, 4-7 September 1979, Ankara, 34p.

Perinçek, D. ve Özkaya, I., 1981. Arabistan Levhası Kuzey Kenarının Tektonik Evrimi. Yerbilimleri, 8, 91-101. 
Postacığlu, B., 1987. Beton, Bağlayıcı Maddeler, Agregalar, Beton, Cilt 2: İstanbul, Teknik Kitaplar Yayınevi, 404s.

Ramsay, D.M., Dhir, R.K. ve Spence, I.M., 1974. The Role of Rock and Clast Fabric in the Physical Performance of Crushed-Rock Aggregate. Engineering Geology, 8(3), 267-285.

Rızaoğlu, T., 2006. Baskil-Sivrice (Elazığ) Arasında Yüzeyleyen Tektono-magmatik Birimlerin Petrografisi ve Jeokimyasi. Doktora Tezi, Cumhuriyet Üniversitesi Fen Bilimleri Enstitüsü, Sivas, 218s.

Selig, E.T. ve Waters, J.M., 1994. Track Geotechnology and Substructure Management: London, Thomas Telford Publications, 446p.

Streckeisen, A., 1976. To Each Plutonic Rock Its Proper Name. Earth Science Reviews, 12(1), 133.

Sungurlu, O., 1979. Güneydoğu Sürüklenim Kuşağ1 Tersiyer Sürüklenimleri, 33. Türkiye Jeoloji Kurultayı Bildirileri, 5-9 Mart 1979, Ankara, s. 121-122.

Şengör, A.M.C., 1979. The North Anatolian Transform Fault: Its Age, Offset and Tectonic Signifiance. Journal of Geological Society London, 136, 269-282.

Şimşek, O., 2003. Yapı Malzemesi II: Ankara, Beta Basım Yayım Dağıtım A.Ş., 211s.

Tasong, W.S., Lynsdale, C.J. ve Cripps, J.C., 1998. Aggregate-Cementpaste Interface: II. Influence of Aggregate Physical Properties. Cement and Concrete Research, 28(10), 1453-1465.

Tayfur, S., Eren, K., Özen, H. ve Yıldırım, S.A., 2003. Sıcak Asfalt Karışımı (BSK) Üretimi Açısından İstanbul Taşocaklarının Genel Değerlendirilmesi: Karşılaşılan Problemler ve Çözüm Önerileri, III Ulusal Kırmataş Sempozyumu, 3-4 Aralık 2003, İstanbul, s.199204.

Temiz, H. Binici, H., Bodur Nuri, M., Kara, O., 2006. Kahramanmaraş Doğal Agregalarının Mühendislik Özellikleri. KSÜ, Fen ve Mühendislik Dergisi. 9(2), 61-65.

TC Devlet Demir Yolları (TCDD), 2017. Balast Taşı Tekink Şartnamesi. Devlet Demiryolları Genel Müdürlüğü, Ankara.

TS EN 1097-3, 1999. Agregaların Fiziksel ve Mekanik Özellikleri İçin Deneyler Bölüm 3: Gevşek Yığın Yoğunluğunun ve Boşluk Hacminin Tayini, Türk Standartları Enstitüsü, Ankara.

TS 7043 EN 13450, 2004. Demiryolu Balastlari için Agregalar, Türk Standartları Enstitüsü, Ankara.
TS 10088 EN 932-3, 2006. Agregaların Genel Özellikleri İçin Deneyler Kısım 3: Basitleştirilmiş Petrografik Tanımlama İçin İşlem ve Terminoloji, Türk Standartları Enstitüsü, Ankara.

TS 706 EN 12620, 2009. Beton Agregaları, Türk Standartları Enstitüsü, Ankara.

TS EN 933-4, 2009. Agregaların Geometrik Özellikleri İçin Deneyler Bölüm 1: Tane Şeklinin Tayini Şekil İndisi, Türk Standartları Enstitüsü, Ankara.

TS EN 1367-2, 2010. Agregaların Termal ve Bozunma Özellikleri İçin Deneyler Bölüm 2: Magnezyum Sülfat Deneyi, Türk Standartları Enstitüsü, Ankara.

TS EN 933-10, 2010. Agregaların Geometrik Özellikleri İçin Deneyler Bölüm 10: İnce Malzeme Tayini - İnce Dolgu Malzemelerinin Tane Büyüklüğüne Göre Sinıflandırılması (Hava Jetiyle Eleme), Türk Standartları Enstitüsü, Ankara.

TS EN 1097-1, 2011. Agregaların Mekanik ve Fiziksel Özellikleri İçin Deneyler Bölüm 1: Aşınmaya Karşı Direncin Tayini (Mikro-Deval), Türk Standartları Enstitüsü, Ankara.

TS EN 933-3, 2012. Agregaların Geometrik Özellikleri İçin Deneyler Bölüm 3: Tane Şekli Tayini Yassılık Endeksi, Türk Standartları Enstitüsü, Ankara.

TS EN 1097-6, 2013. Agregaların Mekanik ve Fiziksel Özellikleri İçin Deneyler Bölüm 6: Tane Yoğunluğu ve Su Emme Oranının Tayini, Türk Standartları Enstitüsü, Ankara.

TS EN 1744-1, 2013. Agregaların Kimyasal Özellikleri İçin Deneyler Bölüm 1: Kimyasal Analiz, Türk Standartları Enstitüsü, Ankara.

TS EN 933-9, 2014. Agregaların Geometrik Özellikleri İçin Deneyler Bölüm 9: İnce Tanelerin Tayini Metilen Mavisi Deneyi, Türk Standartları Enstitüsü, Ankara.

TS EN 1097-2, 2016. Agregaların Mekanik ve Fiziksel Özellikleri İçin Deneyler Bölüm 2: Parçalanma Direncinin Tayini İçin Yöntemler, Türk Standartları Enstitüsü, Ankara.

Turabi, A. ve Okucu, A., 2007. Balıkesir İli Yol Çalışmalarında Kullanılan Agregaların Özellikleri ve Şartnameye Uygunluğu. Balıkesir Üniversitesi Fen Bilimleri Enstitüsü Dergisi, 9(1), 45-51.

Yağız S. 2010. Geomechanical Properties of Construction Stones Quarried in Southwestern 
Turkey. Scientific Research and Essays 5, 750757.

Yazgan, E., 1981. Doğu Toroslar'da Etkin Bir PaleoKita Kenarı Etüdü (Ust Kretase-Orta Eosen). H.U. Yerbilimleri, 7, 83-104.

Yazgan, E., 1983. Geotraverse between the Arabian Platform and the Munzur Nappes. Int. Symp., On the Geology of the Taurus Belt, Field Guide Book for Excursion V, Ankara. p.17.

Yazgan, E., 1984. Geodynamic Evolution of the Eastern Taurus Region (Malatya- Elazı̆g area, Turkey), Proceedings of International Symposium, Geology of Taurus Belt, 26-29 September 1983, Ankara, p. 199-208.

Yeğinobalı, A., 1999. Betonun İç Yapısı. Türkiye Çimento Müstahsilleri Birliği Notları, No: 3, Ankara.

Yılmaz, Y., Yiğitbaş, E. ve Genç, Ş.C., 1993. Ophiolitic and Metamorphic Assemblages of Southeast Anatolia and Their Significance in the Geological Evolution of the Orogenic Belt. Tectonics, 12, 1280-1297.

Yılmaz, A., Saltan, M. ve Akıllı, A., 2012 Göller Yöresinde İşletilen Kireçtaşı Agregalarının Yol İnşaatı Malzemesi Olarak Kullanılabilirliğinin Araştırılması. Pamukkale Üniversitesi Mühendislik Bilimleri Dergisi, 18(3), 199-207.

Yılmaz, A., 2015, Demiryolu Üstyapısında Balast Kirliliği. Mehmet Akif Ersoy Üniversitesi Fen Bilimleri Enstitüsü Dergisi 6(1), 11-17.

Yiğitbaş, E. ve Yılmaz, Y., 1996. New Evidence and Solution to the Maden Complex Controversy of the Southeast Anatolian Orogenic Belt (Turkey). Geologische Rundschau, 85, 250-263.

Zarif, I.H., Tuğrul, A. ve Dursun, G., 2003. İstanbul'daki Kireçtaşlarının Agrega Kalitesi Yönünden Değerlendirilmesi. İstanbul Yerbilimleri Dergisi, 16(1), 61-70.

Zarif, I.H. ve Tuğrul, A., 2003. Aggregate Properties of Devonian Limestones for Use in Concrete in Istanbul, Turkey. Bulletion Engineering Geology and the Environment, 62(4), 379-388. 